\title{
Assessment of Water Mimosa (Neptunia oleracea Lour.) Morphological, Physiological, and Removal Efficiency for Phytoremediation of Arsenic-Polluted Water
}

\author{
Narges Atabaki ${ }^{1}$, Noor Azmi Shaharuddin ${ }^{1,2, *}$, Siti Aqlima Ahmad ${ }^{1}$, Rosimah Nulit $^{3}$ \\ and Rambod Abiri ${ }^{4}$ \\ 1 Department of Biochemistry, Faculty of Biotechnology and Biomolecular Sciences, Universiti Putra Malaysia, \\ UPM, Serdang 43400, Selangor, Malaysia; atabaki.narges@gmail.com (N.A.); aqlima@upm.edu.my (S.A.A.) \\ 2 Institute of Tropical Agriculture and Food Security, Universiti Putra Malaysia, UPM, \\ Serdang 43400, Selangor, Malaysia \\ 3 Department of Biology, Faculty of Science, Universiti Putra Malaysia, UPM, \\ Serdang 43400, Selangor, Malaysia; rosimahn@upm.edu.my \\ 4 Department of Forestry Science and Biodiversity, Faculty of Forestry and Environment, \\ Universiti Putra Malaysia, UPM, Serdang 43400, Selangor, Malaysia; rambod.abiri@gmail.com \\ * Correspondence: noorazmi@upm.edu.my; Tel.: +60-397696724
}

Received: 16 September 2020; Accepted: 16 October 2020; Published: 6 November 2020

\begin{abstract}
Arsenic is considered to be a toxic and heavy metal that exists in drinking water and can lead to acute biotoxicity. Water mimosa (Neptunia oleracea) has been widely identified as a feasible phytoremediator to clean up aquatic systems. In the current study, the phytoremediation potential of water mimosa exposed to different concentrations of sodium heptahydrate arsenate $\left(\mathrm{Na}_{2} \mathrm{HAsO}_{4} \cdot 7 \mathrm{H}_{2} \mathrm{O}\right)$ was tested. A number of plant physiological and growth responses such as height of frond, existence of green leaves, relative growth rate, relative water content, tolerance index, decrease in ratio of biomass and ratio of dry weight, chlorophyll content, photosynthesis rate, intercellular $\mathrm{CO}_{2}$ concentrations, stomatal conductance, air pressure deficit, transpiration rate, proline and lipid peroxidation, as well as arsenic accumulation and removal efficacy were analyzed. The micromorphological analysis results confirmed water mimosa's tolerance of up to $30 \mathrm{ppm}$ of arsenic treatment. The results obtained from the chlorophyll and gas exchange content also showed severe damage by arsenic at doses higher than $30 \mathrm{ppm}$. In addition, the highest arsenic accumulation and arsenic removal efficacy were observed at the range of 30-60 ppm. An analysis of proline and lipid peroxidation content confirmed water mimosa's tolerance of up to $30 \mathrm{ppm}$ of arsenic. The scanning electron microscopy (SEM) and X-ray spectroscopy (EDX) and analysis also confirmed the accumulation of arsenic as shown by the deformation of water mimosa tissues. The results showed that water mimosa is a reliable bioremediator for removing arsenic from aquatic systems.
\end{abstract}

Keywords: phytoremediation; arsenic; Neptunia oleracea; removal efficiency; arsenic accumulation

\section{Introduction}

Environmental pollution is a phenomenon where air, water, and land become unsuitable or unsafe due to the existence of materials harmful towards living organisms [1,2]. Heavy metals including lead $(\mathrm{Pb})$, thallium $(\mathrm{Tl})$, arsenic $(\mathrm{As})$, chromium $(\mathrm{Cr})$, cadmium $(\mathrm{Cd})$, and mercury $(\mathrm{Hg})$ have been categorized as significant contaminants in the environment $[3,4]$. A toxic environment happens as a consequence of the release of heavy metal ions (even in small amounts) from mining, metallurgy, chemical manufacturing, and nuclear energy activities, thus, bringing extreme threats to the Earth's crust [5]. 
Arsenic is an extremely toxic metalloid that is carcinogenic predominantly to humans' liver, lungs, kidney, and bladder. It can also cause nerve damage and skin diseases [6]. This heavy metal is ubiquitous in the Earth's crust with the potential effect of dietetic intake on human health in developed countries. It is also present through atypical groundwater exposure in developing countries and can contaminate the entire water source. These exposures are associated with human diseases, and toxicological concerning doses are comparable to typical dietary intake assessments [7]. The groundwater in the arsenic's presence has affected the water supply to rural areas in over 70 countries. The estimations indicate that the number of people that have been exposed to arsenic is more than 150 million [8]. Inorganic arsenic accumulation in plants, livestock, and contaminated water can be transferred into the food chains [9]. The damage caused by this heavy metal on humans and the environment confirms that the elimination of arsenic from contaminated water is urgently essential. Removing arsenic from the environment through water and its downstream pathways is reportedly a complicated procedure [10]. Novel sustainable and innovative techniques can provide stable and efficient removal procedures of the metal from a water environment [11].

The rapid increase in human population, urbanization, industrial activities, deforestation, exploration, and exploitation of ecosystems has caused heavy metal and metalloid pollutions in Malaysia's environment [12]. It has been detailed that the arsenic concentration is between 2.00 to $54.00 \mu \mathrm{g} / \mathrm{L}$ in rivers across Malaysia [13-17]. This is a concern as it exceeds the international environment guideline which is below $10 \mu \mathrm{g} / \mathrm{L}$ for drinking water samples [18]. To date, several treatment technologies have been announced for the arsenic removal from water bodies [19]. However, it is worth mentioning that the use of the most effective technology depends on plenty of factors such as environmental impact, operational cost and capital investment, the initial metal concentration, and plant reliability and flexibility [20].

Environmental contaminate removal from polluted water, sludge, soil, and sediments using plants is known as phytoremediation [21]. For the past two decades, phytoremediation has been developed as a green, non-invasive, and economic alternative to different conventional civil engineering-based strategies for the remediation of water, soil, and even residences contaminated with heavy metals [22,23]. Strategies employed under phytoremediation have included phytodegradation (employing plants or microorganisms to degrade contaminants) [24-26], phytoaccumulation (employing algae or plants to accumulate contaminants in their areal parts) [27], phytostabilization (employing plants to reduce the heavy metal mobility in soil) [28], phytofiltration (employing plants' biomass and their associated rhizospheric microorganisms to refine contaminants) [27], phytovolatilization (employing plants to absorb contaminants and transpire them into the atmosphere in the volatile shape) [29], and rhizodegradation (employing plants to degrade contaminants using rhizosphere microbes' mediation [30-32] (Figure 1). 


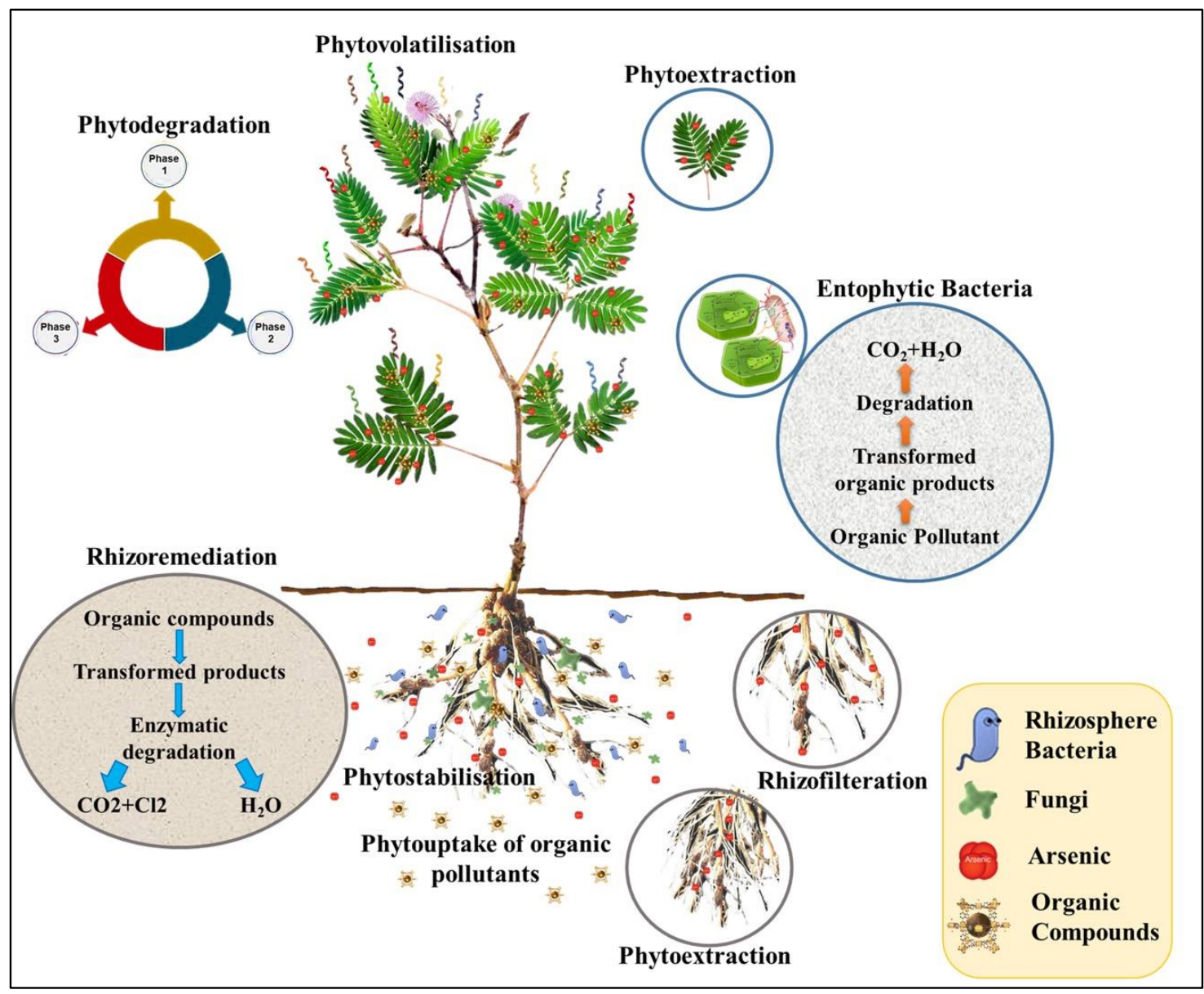

Figure 1. Phytoremediation strategies. The keystone in phytoremediation technologies is contaminants' interactions with plants' rhizosphere. Plants absorb metals from the rhizosphere. Roots take up heavy metals through mobilization. Subsequently, the accumulated metals are translocated to the plants' aerial tissues followed by sequestration in the tissues according to the plants' tolerance, adapted from $[31,33]$.

Aquatic plants are natural candidates for treating contaminated soil and water by accumulating heavy metals in their tissues [34]. In the last five decades, the pantropical mimosoid legume genus Neptunia has awaken considerable interest mainly due to the aquatic habitat of some of its species [35]. The water mimosa (Neptunia oleracea Lour.) is an invasive and aggressive aquatic plant specific to Southeastern Asia, tropical Africa, and India [36]. Reportedly, N. oleracea has been broadly applied for the decontamination or reduction in contaminants in waters surrounding some Asian countries including Malaysia, Thailand, Indonesia, Philippines, and Vietnam [37]. N. oleracea is suitable for phytoremediation based on its short life cycle and growth ease, making it appropriate for planting in contaminated water areas [38]. A comparison with aboveground tissues has shown that heavy metals can accumulate in the root of N. oleracea [39]. The higher accumulation of heavy metals indicated removal efficiency of this plant through the rhizofiltration process [37]. This plant naturally grows in water bodies such as ponds and lakes, as well as rivers in Malaysia, therefore, providing some advantages in their planting and application such as high level of treatment, being evergreen, has high biomass production, has good adaptation to the tropical climate, is inexpensive, and requires simple maintenance [40].

Given the above, the main objective of the current study is to elucidate the influence of different arsenic contaminations on the morphological, physiological, as well as histological characteristics of $N$. oleracea lour. In addition, the present investigation aims to provide insight regarding removal efficiency of water mimosa for phytoremediation of arsenic-polluted water. 


\section{Results and Discussion}

\subsection{Macromorphological Observation of Water Mimosa under Different Arsenic Concentrations}

In the current study, a hydroponic experiment was carried out to evaluate the impact of sodium heptahydrate arsenate $\left(\mathrm{Na}_{2} \mathrm{HAsO}_{4} \cdot 7 \mathrm{H}_{2} \mathrm{O}\right)$ on the growth performance and development of $N$. oleracea (water mimosa). Furthermore, the phytoremediation potential was tested by measuring the water mimosa's ability to accumulate arsenic. In this study, nondestructive morphological observations were measured on the first and 14th days. Quantitative and qualitative observations of the plants on the first and 14th days showed that the growth and reactions of the water mimosas varied in response to the different arsenic treatment concentrations (Figure 2). The addition of arsenic negatively influenced the morphological appearance of treated water mimosas. Increased arsenic concentrations over time caused the number and growth ratio of leaves and roots, as well as root and shoot diameters decreased. Morphological observations showed that after 14 days, water mimosas were resistant to low levels of arsenic concentrations (less than 60 ppm) (Figure 2i,m,n,o). Nonetheless, increasing the arsenic concentrations to $60 \mathrm{ppm}$ had severe effects which caused serious damage followed by the death of the plants (Figure 2q-t). Increasing the arsenic levels to more than $70 \mathrm{ppm}$ led to significant changes in the plants' characteristics. At higher arsenic concentrations, the morphological analysis showed severe symptoms of damage, and ultimately, the death of the plants (Figure $2 \mathrm{r}-\mathrm{t}$ ).

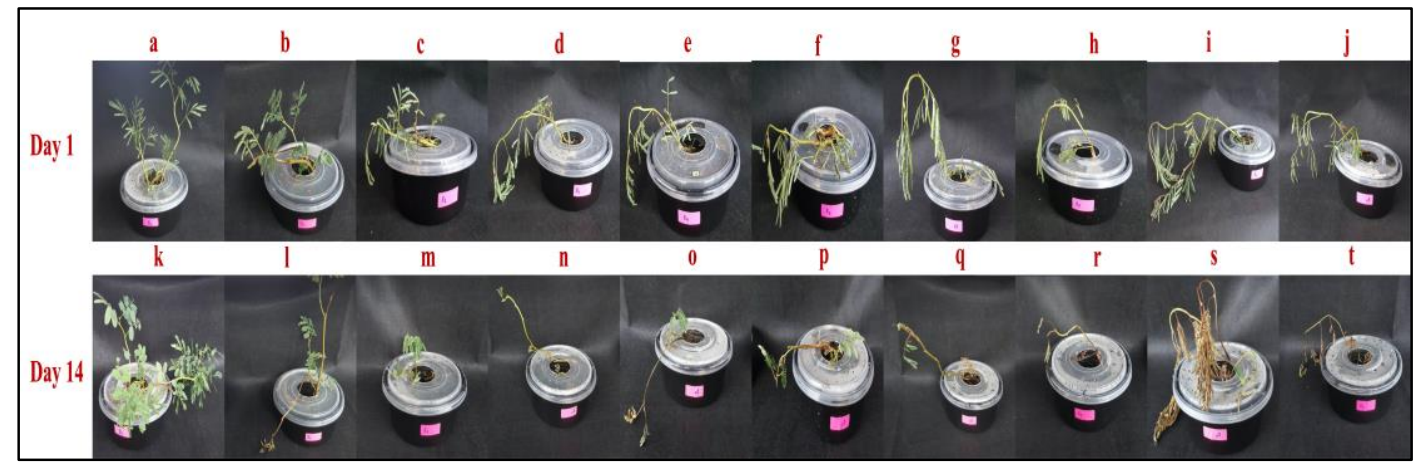

Figure 2. Exposure of water mimosas to different concentrations of arsenic (control, 5, 10, 30, 50, 60, 70, 80,90 , and $100 \mathrm{ppm}$ ). A total of 20 tanks were used, and plants were distributed in 3 experimental blocks (10 arsenic concentrations $\times 3$ replications). Each tank $(12 \times 25 \times 10 \mathrm{~cm}=3 \mathrm{~L})$ contained a single plant. The control and treated plants were kept at $18-25^{\circ} \mathrm{C}$ with an $18 \mathrm{~h} \mathrm{light} / 6 \mathrm{~h}$ dark photoperiod under a light intensity of $500 \mu \mathrm{mol} \cdot \mathrm{m}^{-2}$ for two weeks. The data were collected on the $1 \mathrm{st}$ and $14 \mathrm{th}$ days. Morphological analysis showed that water mimosas were resistant to low levels of arsenic concentrations (less than $60 \mathrm{ppm}$ ). At higher arsenic concentrations, the morphological analysis showed severe symptoms of damage, and ultimately, death of the plant. Collected qualitative and quantitative data confirmed the negative impact of arsenic when its concentrations and time of treatment were increased. Day 1, control = a, $5 \mathrm{pp}=\mathrm{b}, 10 \mathrm{pp}=\mathrm{c}, 30 \mathrm{pp}=\mathrm{d}, 50 \mathrm{ppm}=\mathrm{e}, 60 \mathrm{ppm}=\mathrm{f}, 70 \mathrm{ppm}=\mathrm{g}$, $80 \mathrm{ppm}=\mathrm{h}, 90 \mathrm{ppm}=\mathrm{i}$, and $100 \mathrm{ppm}=\mathrm{j}$. Day 14, control $=\mathrm{k}, 5 \mathrm{pp}=\mathrm{l}, 10 \mathrm{pp}=\mathrm{m}, 30 \mathrm{pp}=\mathrm{n}, 50 \mathrm{ppm}=\mathrm{o}$, $60 \mathrm{ppm}=\mathrm{p}, 70 \mathrm{ppm}=\mathrm{q}, 80 \mathrm{ppm}=\mathrm{r}, 90 \mathrm{ppm}=\mathrm{s}$, and $100 \mathrm{ppm}=\mathrm{t}$.

Measurement of the plants' morphological traits was the initial step taken to observe the phytoremediation potential of water mimosas against heavy metals. In Cd-treated Bromus kopetdaghensis, decreasing trends were reported for a majority of morphological characteristics such as root and shoot height, and dry weight [41]. Similarly, reductions in the morphological traits of Prosopis laevigata were reported under heavy metal treatment. It has been documented that plants with phytoremediation properties absorbed heavy metals, and this absorbance could cause severe damage at higher levels of toxicities. The colors of leaves and plants, number of leaves, and structure of roots and shoots are part of the morphological features that can be observed to degrade at the early stages of toxicity [42]. Since water mimosas are fast-growing aquatic plants, they can absorb nutrients and heavy metal 
rapidly. The absorbed nutrients/heavy metal can be transferred easily to the areal parts and leaves and present their impact on the morphology of the plant [37]. In this study, the color of leaves had turned yellow and, after seven days, wilting had occurred. Increasing the treatment time up to 14 days caused the plants' color to change to brownish, followed by the plants' death at the final stage. The roots of water mimosas placed under control conditions were thinner than the roots of plants treated with arsenic (woody roots) (Figure 3). After increasing the arsenic level, the leaves' color changed from greenish to yellowish and, ultimately, died. The changes in leaves' morphology started at the early stages of treatment, but significant changes were observed on Day 14. Leaves had dropped for water mimosas treated with arsenic concentrations of 50 ppm and above, at Day 7. At Day 14, the arsenic's toxicity was observed clearly through the leaves' survival rate and color at higher concentrations. At the end of the experiment, the color of roots changed from pinkish to brownish. The leaves of the control plants remained green and normal in shape. The stems of plants under control were straight; however, the stems of plants treated with arsenic were near the surface of the tanks. It has been reported that the leaves of water mimosas make rapid movements in response to touch [43]. The leaves' movement showed different reactions in response to light and strong touch. Water flux across the tonoplast/plasma membrane, and the parallel leaves reaction are relevant to the water channel aquaporin as a particular membrane protein [44]. In this experiment, the authors observed that the leaves of water mimosas treated with arsenic showed the same reactions when they were touched. For lower levels of arsenic treatment at shorter treatment periods, the leaves of the water mimosas were folded at points (pulvinules) along the rib (rachis). However, when the levels of arsenic were increased for longer durations, the branches and leaves dropped together at the pulvinus zone where the main branch (petiole) joins the stem [44].

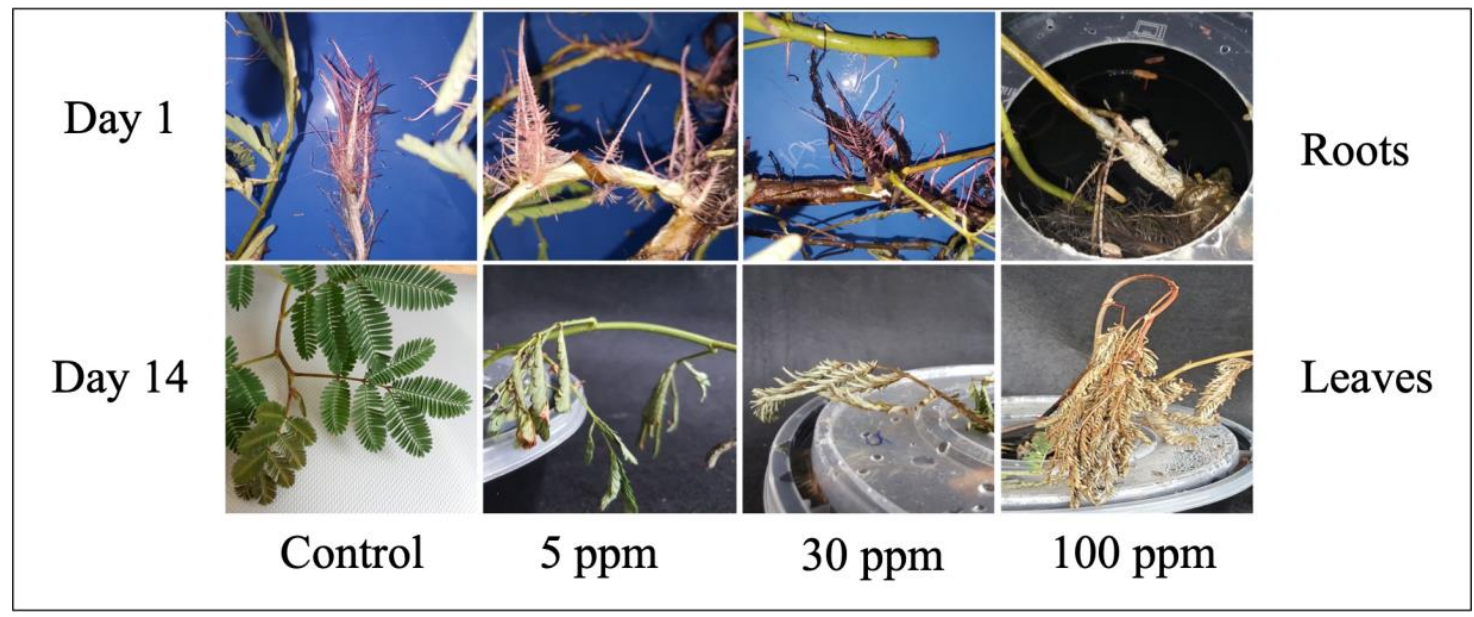

Figure 3. Samples of water mimosas' leaves and roots under arsenic treatment (control, 5, 30, and $100 \mathrm{ppm})$ after 1 and 14 days. Each tank $(12 \times 25 \times 10 \mathrm{~cm}=3 \mathrm{~L})$ contained a single plant. The control and treated plants were kept at $18-25^{\circ} \mathrm{C}$ with an $18 \mathrm{~h}$ light $/ 6 \mathrm{~h}$ dark photoperiod under a light intensity of $500 \mu \mathrm{mol} \cdot \mathrm{m}^{-2}$ for two weeks. Increasing the arsenic levels and the time caused deformation of water mimosa's parts, necrosis, chlorosis, and yellowing of leaves, as well as root hardening and woody formation.

\subsection{Physiological Changes of Water Mimosa under Arsenic Treatment}

\subsubsection{Arsenic's Impact on Micromorphological Traits of Water Mimosa}

ANOVA and Duncan's multiple comparison tests of the arsenic impact on the water mimosas were significant $(p \leq 0.01)$ in terms of decreasing ratio of biomass (DRB) and decreasing ratio of dry weight (DRD). Nonsignificant differences were observed between the replicates (Table 1). 
Table 1. ANOVA results of water mimosas' decreasing ratio of biomass (DRB) and decreasing ratio of dry weight (DRD) under various concentrations of arsenic treatment.

\begin{tabular}{cccc}
\hline S.O.V & df & DRB & DRD \\
\hline Concentration & 9 & $0.6241^{\text {** }}$ & $0.66^{* *}$ \\
Replicate & 2 & $0.001^{\mathrm{ns}}$ & $0.004^{\mathrm{ns}}$ \\
Error & 18 & 0.0006 & 0.0043 \\
Total & 29 & - & - \\
\hline C.V. & - & 3.08 & 7.818 \\
\hline
\end{tabular}

S.O.V, source of variation. ${ }^{* *}$ significant at the 0.01 probability levels. ns, non significant. DRB: decreasing ratio of biomass and DRD: decreasing ratio of dry weight (DRD).

The most considerable biomass belonged to the control plants where the least decreasing ratio of biomass (DRB) recorded was $0.69 \%$ (Figure 4a). However, the comparison with the control plants showed that the lowest DRB observed among plants treated with $5 \mathrm{ppm}$ arsenic was a $6.7 \%$ reduction after 14 days. Additionally, the highest reduction in the DRB belonged to plants treated with $100 \mathrm{ppm}$ arsenic at $93.7 \%$. The DRB significantly increased up to $70 \mathrm{ppm}$ arsenic concentration followed by a decreasing trend at $90 \mathrm{ppm}$ and another increasing rate at $100 \mathrm{ppm}$. According to Duncan's multiple comparison test, plants treated with 30 and $50 \mathrm{ppm}$ arsenic treatments were in the same group (non-significant differences), while those treated using 70, 80, and $100 \mathrm{ppm}$ concentrations of arsenic were in the same group, and non-significant differences were observed (Figure 4a). The highest dry weight belonged to the control plants in which the least decreasing ratio of dry weight (DRD) was observed in water mimosas at $0.7 \%$ (Figure $4 \mathrm{~b}$ ). Although the highest DRD was observed for plants treated in $100 \mathrm{ppm}(93.75 \%)$ arsenic followed by $80 \mathrm{~mL} / \mathrm{L}$ arsenic $(92.93 \%)$, non-significant differences were seen for plants treated using 70, 80, 90, and 100 ppm arsenic concentrations (Figure 4b). Comparing all treatments, the lowest DRD was reported for plants under 5 ppm arsenic concentration at $16.61 \%$ (Figure $4 \mathrm{~b}$ ). The DRD significantly increased for plants treated up to $70 \mathrm{ppm}$ concentrations of arsenic, followed by a slight increase in the rest of the concentrations (Figure $4 \mathrm{~b}$ ).

The effects of arsenic on the height of frond percentage, green leaves percentage, relative growth rate (RGR) percentage, relative water content (RWC), and tolerance index (Ti) of water mimosas at different concentrations are reported in Table 2. The highest height of frond was observed in control plants (5\%) and the lowest height of frond was reported for plants under $100 \mathrm{ppm}$ arsenic treatment after 14 days (Table 2). However, a non-significant difference was observed between the control plants and plants treated with 5 ppm arsenic (Table 2). The percentage of green leaves also decreased after 14 days with increasing arsenic concentrations (Table 2). The RGR in water mimosas presented decreased ratios with an increase in arsenic concentrations. The RGR for water mimosas under the control condition (no arsenic) was $0.004 \mathrm{~g} / \mathrm{g} \cdot$ day, a two-fold decrease $(0.002 \mathrm{~g} / \mathrm{g} \cdot$ day) from the plants treated with $5 \mathrm{ppm}$ arsenic. A decreasing trend was also reported in water mimosas under $10 \mathrm{ppm}$ arsenic treatment. However, no PGR was observed in plants under the highest levels of arsenic treatment (Table 2). The highest RWC was observed in water mimosas treated with $100 \mathrm{ppm}$ arsenic and the lowest RWC was reported in plants under control (free of arsenic). In addition, the highest and lowest tolerance indices were presented in the control plants and water mimosas under $100 \mathrm{ppm}$ arsenic treatment, respectively (Table 2). 

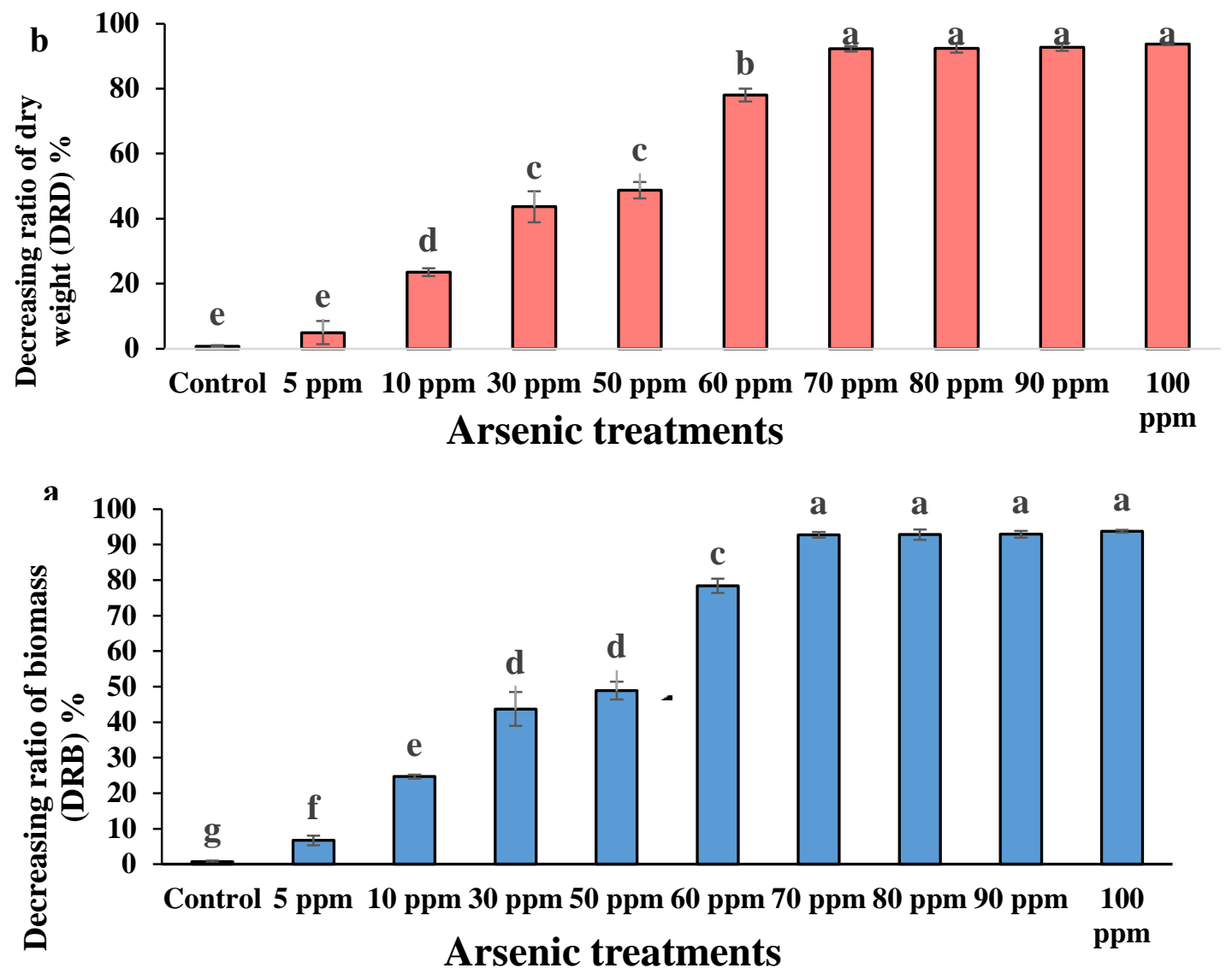

Figure 4. (a) Decreasing ratio of biomass (DRB) (\%) and (b) decreasing ratio of dry weight (DRD) (\%) of water mimosas two weeks after treatment in different arsenic concentrations $(0,5,10,30,50,60$, $70,80,90$, and 100 ppm). Fresh and dry weight of plants were measured on the 1st and 14th days. One-way ANOVA was performed, and bars represent standard errors (SE) of the means of the treatments $(n=3)$ with the same species, if not otherwise stated. Different letters indicate significant differences between arsenic concentrations according to Duncan's multiple range test $(p \leq 0.05)$.

Table 2. Height of frond percentage, green leaves percentage, relative growth rate (RGR) percentage, relative water content (RWC), and tolerance index of water mimosas under different arsenic concentrations.

\begin{tabular}{cccccc}
\hline $\begin{array}{c}\text { Arsenic Concentrations } \\
(\mathbf{p p m})\end{array}$ & $\begin{array}{c}\text { Height of } \\
\text { Frond (\%) }\end{array}$ & $\begin{array}{c}\text { Green Leaves } \\
\mathbf{( \% )}\end{array}$ & $\begin{array}{c}\text { RGR } \\
(\mathbf{g} / \mathbf{g} \cdot \text { day })\end{array}$ & $\begin{array}{c}\text { RWC } \\
\mathbf{( \% )}\end{array}$ & $\begin{array}{c}\text { Ti } \\
(\mathbf{\%})\end{array}$ \\
\hline $\begin{array}{c}\text { Control } \\
\mathbf{5}\end{array}$ & $5 \pm 0.2^{\mathrm{a}}$ & $100 \pm 0.0^{\mathrm{a}}$ & $0.004 \pm 0.00076^{\mathrm{a}}$ & $89.34 \pm 1.12^{\mathrm{d}}$ & $100^{\mathrm{d}} \pm 0.00^{\mathrm{a}}$ \\
$\mathbf{1 0}$ & $5 \pm 0.44^{\mathrm{a}}$ & $96 \pm 1.43^{\mathrm{b}}$ & $0.002 \pm 0.00023^{\mathrm{b}}$ & $90.56 \pm 1.34^{\mathrm{cd}}$ & $85 \pm 1.2^{\mathrm{b}}$ \\
$\mathbf{3 0}$ & $4.5 \pm 0.34^{\mathrm{b}}$ & $89 \pm 1.76^{\mathrm{c}}$ & $0.001 \pm 0.00012^{\mathrm{bc}}$ & $90.67 \pm 2.32^{\mathrm{c}}$ & $73^{\mathrm{c}} \pm 1.5^{\mathrm{c}}$ \\
$\mathbf{5 0}$ & $3.7 \pm 0.36^{\mathrm{c}}$ & $71 \pm 0.32^{\mathrm{d}}$ & $0.00 \pm 0.0^{\mathrm{d}}$ & $91.02 \pm 1.12^{\mathrm{bc}}$ & $61 \pm 1.23^{\mathrm{d}}$ \\
$\mathbf{6 0}$ & $2.2 \pm 0.24^{\mathrm{d}}$ & $46 \pm 0.24^{\mathrm{e}}$ & $0.00 \pm 0.0^{\mathrm{d}}$ & $91.03 \pm 2.35^{\mathrm{bc}}$ & $47 \pm 1.43^{\mathrm{e}}$ \\
$\mathbf{7 0}$ & $1.5 \pm 0.12^{\mathrm{e}}$ & $32 \pm 1.43^{\mathrm{f}}$ & $0.00 \pm 0.0^{\mathrm{d}}$ & $91.2 \pm 3.23^{\mathrm{ab}}$ & $34 \pm 1.84^{\mathrm{f}}$ \\
$\mathbf{8 0}$ & $1.5 \pm 0.23^{\mathrm{e}}$ & $29 \pm 0.32^{\mathrm{f}}$ & $0.00 \pm 0.0^{\mathrm{d}}$ & $91.23 \pm 2.22^{\mathrm{ab}}$ & $26 \pm 0.98^{\mathrm{g}}$ \\
$\mathbf{9 0}$ & $1.2 \pm 0.25^{\mathrm{e}}$ & $7 \pm 1.21^{\mathrm{g}}$ & $0.00 \pm 0.0^{\mathrm{d}}$ & $91.3 \pm 1.33^{\mathrm{a}}$ & $22 \pm 1.72^{\mathrm{h}}$ \\
$\mathbf{1 0 0}$ & $0.9 \pm 0.23^{\mathrm{f}}$ & $0.00 \pm 0.0^{\mathrm{e}}$ & $0.00 \pm 0.0^{\mathrm{d}}$ & $91.32 \pm 1.21^{\mathrm{a}}$ & $20 \pm 1.32^{\mathrm{i}}$ \\
\hline
\end{tabular}

Plant growth and physiological parameters were measured on the 14th day of experiment. RWC, relative water content; RGR, relative growth rates; and Ti, tolerance index. Different letters indicate significant differences between arsenic concentrations according to Duncan's multiple range test $(p \leq 0.05)$.

Each of the arsenic concentrations applied to the water mimosas had significant detrimental effects on the plants' growth and development. These results are in parallel with reports on other high-tolerance species such as Salix purpurea (Purple willow) [45], Pteris vittata (Chinese brake) [46], 
Oryza sativa (rice) [47], and Typha latifolia [48]. It has been shown that severe concentration of arsenic dosages inhibited the normal life cycle of plants and in the detrimental phase, could kill plants. Changes in the dry and fresh weights of plants under arsenic treatment revealed that arsenic directly affected photosynthesis, the life cycle of cells, and plants' receptors [49,50]. Generally, plants can tolerate heavy metals like arsenic using developed mechanisms such as transporting heavy metals through internal tolerance mechanisms or limiting the absorption by cascades of changes from a plant's receptors and maintaining its cell structure [51]. Although increased concentrations of heavy metals such as arsenic decreased plants' tolerance, it has been shown that plants with tolerance indices of more than $60 \%$ were assumed to be good tolerant bioreactors [52]. The results demonstrated good tolerance to arsenic by water mimosa plants exposed to $30 \mathrm{ppm}$ after 14 days. However, the Ti value of the water mimosas showed that the plant also had good tolerance to arsenic after exposed to $60 \mathrm{ppm}$ over 7 days (data are not presented). The decreasing trend of RGR was reported due to an increase in biomass over time [53]. The combined micro-morphological data analyses of Ti, RWC, RGR, green leaves, and the height of frond indicate that water mimosas display good capacity for growth, metal bioconcentration, and tolerance up to 14 days under 30 ppm of arsenic exposure.

\subsubsection{Impact of Arsenic on Physiological Traits of Water Mimosa}

The ANOVA and Duncan's multiple comparison tests on the water mimosas were significant $(p \leq 0.01)$ in terms of photosynthesis rate, stomatal conductance, transpiration rate, and chlorophyll content. Non-significant differences were observed between the replicates (Table 3). The ANOVA analysis of water mimosa also showed significant differences at the $5 \%$ level after seven days, and significant differences at the $1 \%$ level after 14 days of intercellular $\mathrm{CO}_{2}$ concentration (Table 3). The ANOVA analysis also showed non-significant differences after seven days and significant differences $(p \leq 0.05)$ after 14 days of air pressure deficit (Table 3).

Table 3. ANOVA results of water mimosas' chlorophyll content, photosynthesis rate, conductance to $\mathrm{H}_{2} \mathrm{O}$, intercellular $\mathrm{CO}_{2}$ concentrations, transpiration rate, and vapor pressure deficit based on leaf temperature under various concentrations of arsenic treatment.

\begin{tabular}{|c|c|c|c|c|c|c|c|c|c|c|c|c|c|}
\hline \multirow{2}{*}{ S.O.V } & \multirow{2}{*}{$\mathrm{df}$} & \multicolumn{2}{|c|}{$\begin{array}{c}\text { Chlorophyll } \\
\text { Content }\end{array}$} & \multicolumn{2}{|c|}{$\begin{array}{c}\text { Photosynthesis } \\
\text { Rate }\end{array}$} & \multicolumn{2}{|c|}{$\begin{array}{c}\text { Stomata } \\
\text { Conductance }\end{array}$} & \multicolumn{2}{|c|}{$\begin{array}{c}\text { Intercellular } \mathrm{CO}_{2} \\
\text { Concentrations }\end{array}$} & \multicolumn{2}{|c|}{$\begin{array}{l}\text { Transpiration } \\
\text { Rate }\end{array}$} & \multicolumn{2}{|c|}{ Air Pressure Deficit } \\
\hline & & Week 1 & Week 2 & Week 1 & Week 2 & Week 1 & Week 2 & Week 1 & Week 2 & Week 1 & $\begin{array}{c}\text { Week } \\
2\end{array}$ & Week 1 & Week 2 \\
\hline Concentration & 9 & $173.6^{* *}$ & $201.7^{* *}$ & $50.53^{* *}$ & $25.82^{* *}$ & $0.0065^{* *}$ & $0.008^{* *}$ & $39,106.1^{*}$ & $32,985.5^{* *}$ & $1.77^{* *}$ & $3.64^{* *}$ & $0.065^{\mathrm{ns}}$ & $0.188^{*}$ \\
\hline Replicate & 2 & $1.12^{\mathrm{ns}}$ & $0.36^{\mathrm{ns}}$ & $0.106^{\mathrm{ns}}$ & $3.45^{\mathrm{ns}}$ & $0.0002^{\mathrm{ns}}$ & $0.001^{\mathrm{ns}}$ & $6335.9^{\mathrm{ns}}$ & $383.87^{\mathrm{ns}}$ & $0.024^{\mathrm{ns}}$ & $0.02^{\mathrm{ns}}$ & $0.048^{\mathrm{ns}}$ & $0.067^{\mathrm{ns}}$ \\
\hline Error & 18 & 89.53 & 65.14 & 0.358 & 2.99 & 0.0007 & 0.001 & $11,974.96$ & 518.67 & 0.202 & 0.372 & 0.032 & 0.07184 \\
\hline Total & 29 & - & - & - & - & - & - & - & - & - & - & - & - \\
\hline C.V. & - & 11.35 & 10.41 & 20.34 & 19.6 & 18.22 & 16.55 & 34.33 & 10.47 & 19.97 & 20.32 & 8.698 & 14.42 \\
\hline
\end{tabular}

The results of the photosynthetic activities test showed that the highest net photosynthesis rate was observed for the controlled water mimosas at $11.69 \mu \mathrm{mol} \mathrm{CO} \mathrm{m}^{-2} \cdot \mathrm{s}^{-1}$ (Figure 5a). A comparison of all treatments showed that the highest photosynthesis rate of the water mimosa plants was obtained from those treated with $5 \mathrm{ppm}$ arsenic at $0.99 \mu \mathrm{mol} \mathrm{CO}_{2} \mathrm{~m}^{-2} \cdot \mathrm{s}^{-1}$, while the lowest total photosynthesis rate was recorded for those treated in $100 \mathrm{ppm}$ arsenic at $0.12 \mu \mathrm{mol} \mathrm{CO} \mathrm{C} \mathrm{m}^{-2} \cdot \mathrm{s}^{-1}$. A decreasing trend of photosynthesis rate was also observed in Bambusa vulgaris. At the detrimental phases, the heavy metal destroyed the leaves completely and led to the plants' death [54]. In other reports, arsenic has been shown to cause oxidative stress, a decrease in photosynthesis rate, and inhibit growth parameters in Neem (Azadirachta indica) and Tulsi (Ocimum sanctum). These changes occurred due to a decrease in leaf sizes, alteration of stomatal pores, and deformation of leaves [55]. Although the photosynthetic rates of some rice cultivars increased, intercellular $\mathrm{CO}_{2}$ concentrations, conductance to $\mathrm{H}_{2} \mathrm{O}$, and transpiration rate decreased under arsenic stress [56]. Additionally, the highest stomatal conductance rates were obtained for control plants at $0.17 \mathrm{~mol} \mathrm{H}_{2} \mathrm{O} \mathrm{m}^{-2} \cdot \mathrm{s}^{-1}$ followed by those treated with $5 \mathrm{ppm}$ of arsenic at $0.084 \mathrm{~mol} \mathrm{H}_{2} \mathrm{O} \mathrm{m}^{-2} \cdot \mathrm{s}^{-1}$, whereas the lowest total stomatal conductance rate was recorded in plants 
treated with $100 \mathrm{ppm}$ arsenic at $0.007 \mathrm{~mol} \mathrm{H}_{2} \mathrm{O} \mathrm{m}^{-2} \cdot \mathrm{s}^{-1}$ after 14 days (Figure $5 \mathrm{~b}$ ). Stomatal conductance under high concentrations of arsenic was slightly reduced on Day 14 (Figure 5b).

Therefore, arsenic has been proven to directly or indirectly affect plants' photosynthetic functions. This suggests that under heavy metal stress, carbon assimilation is reduced, a situation which can directly inhibit plant growth. The arsenic treatment caused a considerable decreasing trend of stomatal conductance which could be the consequence of stomatal closure or nonstomatal inhibition of photosynthesis [54]. This reduced rate of stomatal conductance could also have been caused by leaf damage and subtended stomata in treated plants. These results were similar to the results of an assessment on B. vulgaris after exposure to heavy metals [54]. Low stomatal conductance, root absorption rate, water content, compatible solute of arsenic accumulation, osmotic potential, and leaf conducting tissues were reported as general features of plants under heavy metal stress [57].

The highest intercellular $\mathrm{CO}_{2}$ concentration was reported for plants treated with $90 \mathrm{ppm}$ arsenic concentration at $527.82 \mu \mathrm{mol} \mathrm{CO} \mathrm{mol}^{-1}$ after 7 days (Figure 5c). However, the lowest intercellular $\mathrm{CO}_{2}$ concentration for water mimosas was recorded for plants treated with $5 \mathrm{ppm}$ arsenic at $201.08 \mu \mathrm{mol}$ $\mathrm{CO}_{2} \mathrm{~mol}^{-1}$ after 7 days. The highest intercellular $\mathrm{CO}_{2}$ concentration was observed for plants under $90 \mathrm{ppm}$ arsenic concentration at $367.96 \mu \mathrm{mol} \mathrm{CO}_{2} \mathrm{~mol}^{-1}$ after 14 days (Figure 5c). However, the lowest intercellular $\mathrm{CO}_{2}$ concentration for water mimosas was recorded for those under $60 \mathrm{ppm}$ arsenic concentration at $93.47 \mu \mathrm{mol} \mathrm{CO} \mathrm{mol}^{-1}$, followed by plants under $50 \mathrm{ppm}$ arsenic concentration at $94.60 \mu \mathrm{mol} \mathrm{CO}_{2} \mathrm{~mol}^{-1}$ after 14 days. The intercellular $\mathrm{CO}_{2}$ concentration decreased slightly on Day 14, especially for plants under higher concentrations of arsenic treatment. The results of an investigation on $\mathrm{O}$. sativa showed that intercellular $\mathrm{CO}_{2}$ concentrations, conductance to $\mathrm{H}_{2} \mathrm{O}$, and transpiration rate had significantly decreased after treatment [56]. These findings were in the same trend as the results on water hyacinth after 14 days of arsenic treatment [56]. In a study on other heavy metals' effects on intercellular $\mathrm{CO}_{2}$ concentrations, lettuce plants (Lactuca sativa) exposed to low doses of $\mathrm{Pb}\left(\mathrm{NO}_{3}\right)_{2}$ for 28 days showed negative effects in terms of $\mathrm{CO}_{2}$ assimilation. However, the transpiration rate, intercellular $\mathrm{CO}_{2}$ concentration, and stomatal conductance were not affected, and the lettuce plants did not display clear growth impairment or even morphological changes [58]. These results were similar to the response obtained from water mimosas treated with different arsenic concentrations in terms of intercellular $\mathrm{CO}_{2}$ concentrations after seven days of treatment.

The highest transpiration rate was obtained in control samples at $3.31 \mathrm{mmol} \mathrm{H}_{2} \mathrm{O} \mathrm{m}^{-2} \cdot \mathrm{s}^{-1}$ followed by those under $50 \mathrm{ppm}$ arsenic treatment at $1.13 \mathrm{mmol} \mathrm{H} \mathrm{O} \mathrm{m}^{-2} \cdot \mathrm{s}^{-1}$. Contrariwise, the lowest transpiration rate was recorded in plants treated with $90 \mathrm{ppm}$ arsenic at $0.14 \mathrm{mmol} \mathrm{H}_{2} \mathrm{O} \mathrm{m}^{-2} \cdot \mathrm{s}^{-1}$, followed by those treated with $100 \mathrm{ppm}$ arsenic at $0.15 \mathrm{mmol} \mathrm{H}_{2} \mathrm{O} \mathrm{m}^{-2} \cdot \mathrm{s}^{-1}$ (Figure $5 \mathrm{~d}$ ). Arsenic accumulation also caused significant poor growth due to enhancements to the peroxidation lipid and content hydrogen peroxide which led to a significant reduction in the transpiration rate, photosynthesis rate, and stomatal conductance of Ricinus communis genotypes $[59,60]$. Inhibition of the transpiration rate was caused by stomata closure [61,62], xylem embolism [63], and leaf damage [64]. In the current research, the results indicated that plants treated with different concentrations of arsenic suffered a significant decline in transpiration rate as compared with the controls. The same results in gas exchange attributes were observed in a study that focused on the effect of arsenic toxicity on the photosynthesis growth of rice seedlings, and recorded that higher durations of arsenic treatment caused a greater decline in transpiration rates [55]. 


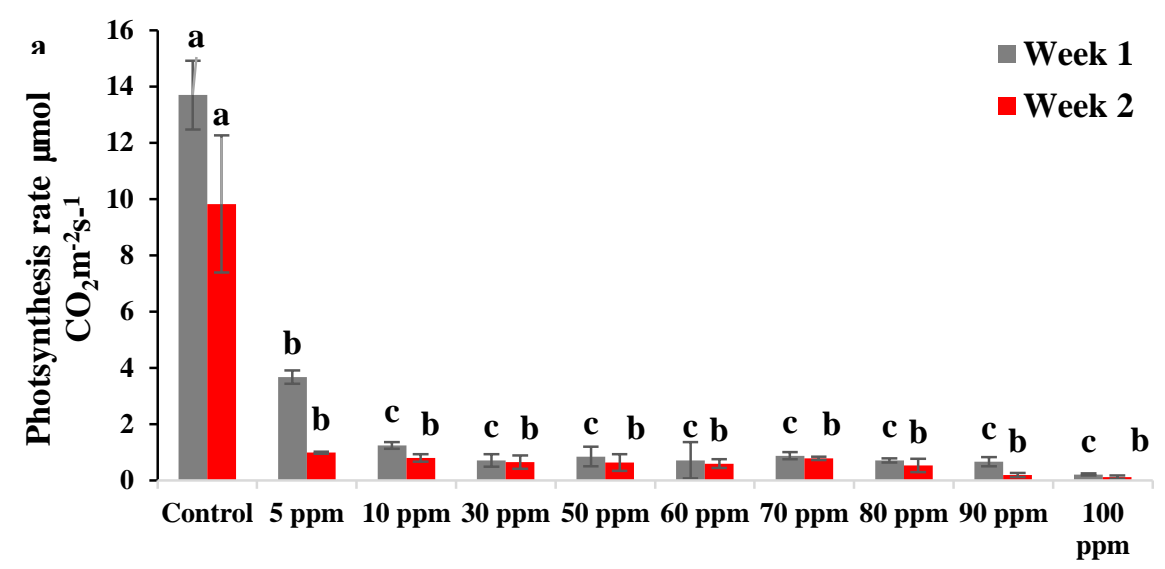

Arsenic treatments
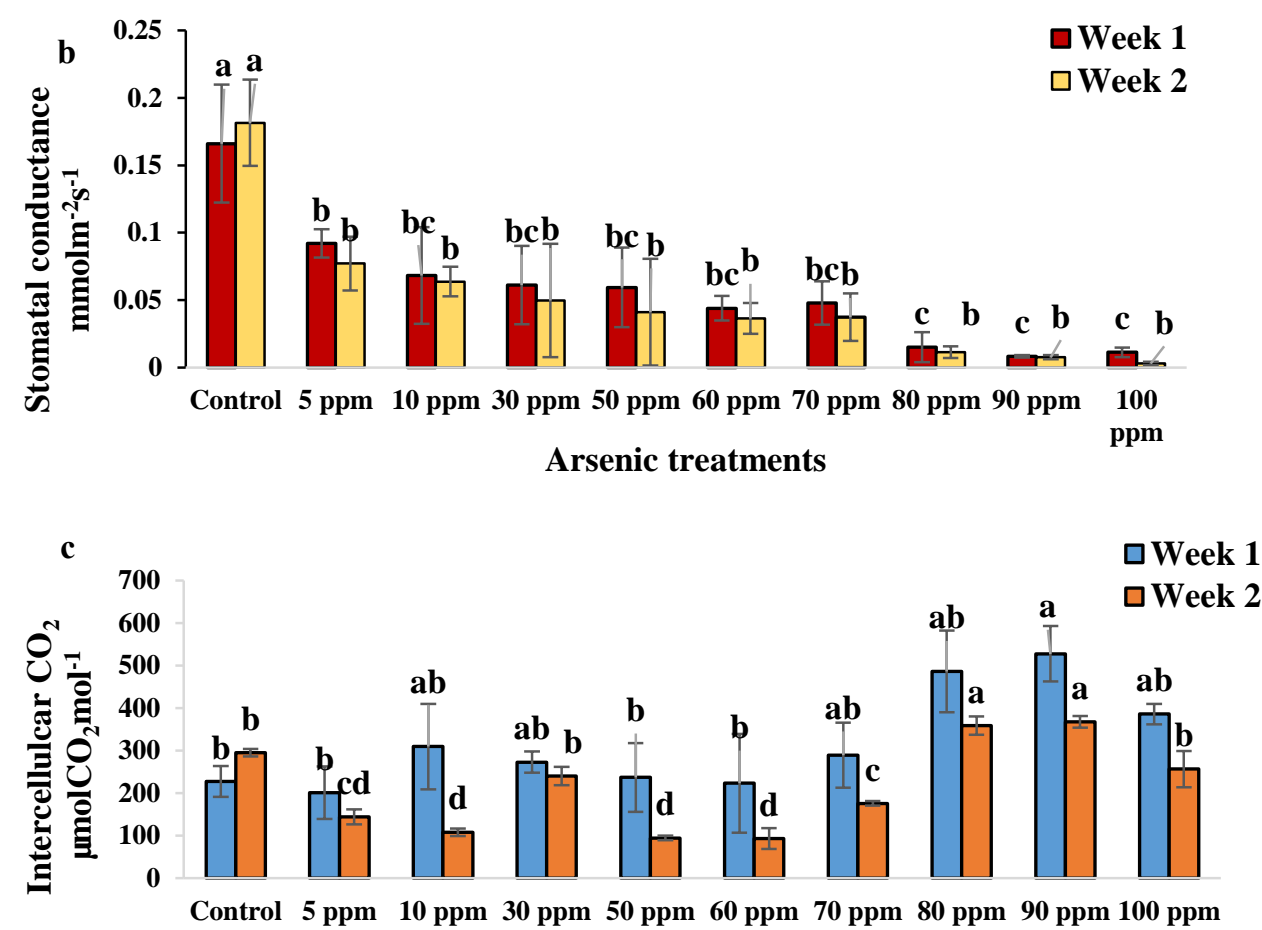

Arsenic treatments

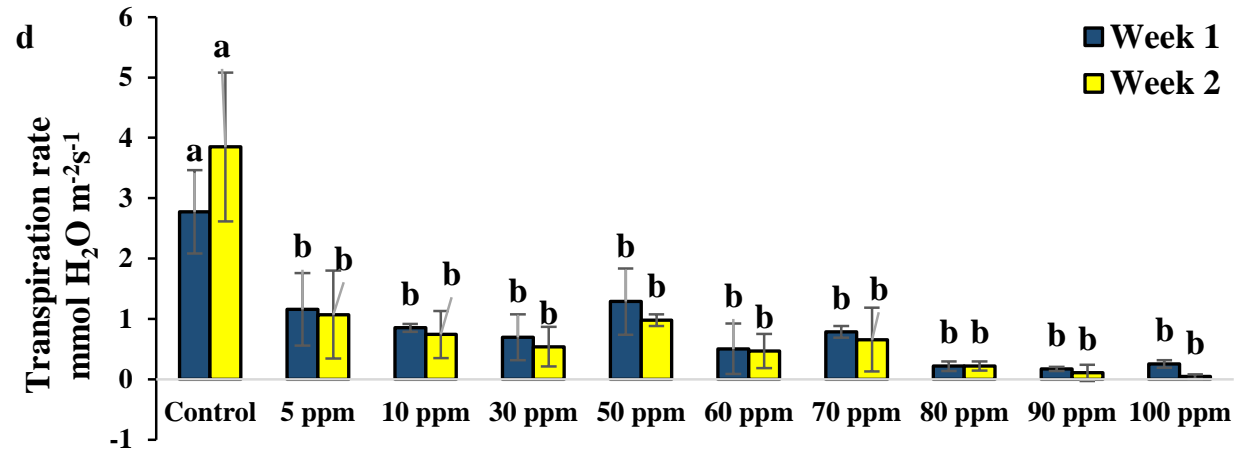

Arsenic treatments

Figure 5. Cont. 

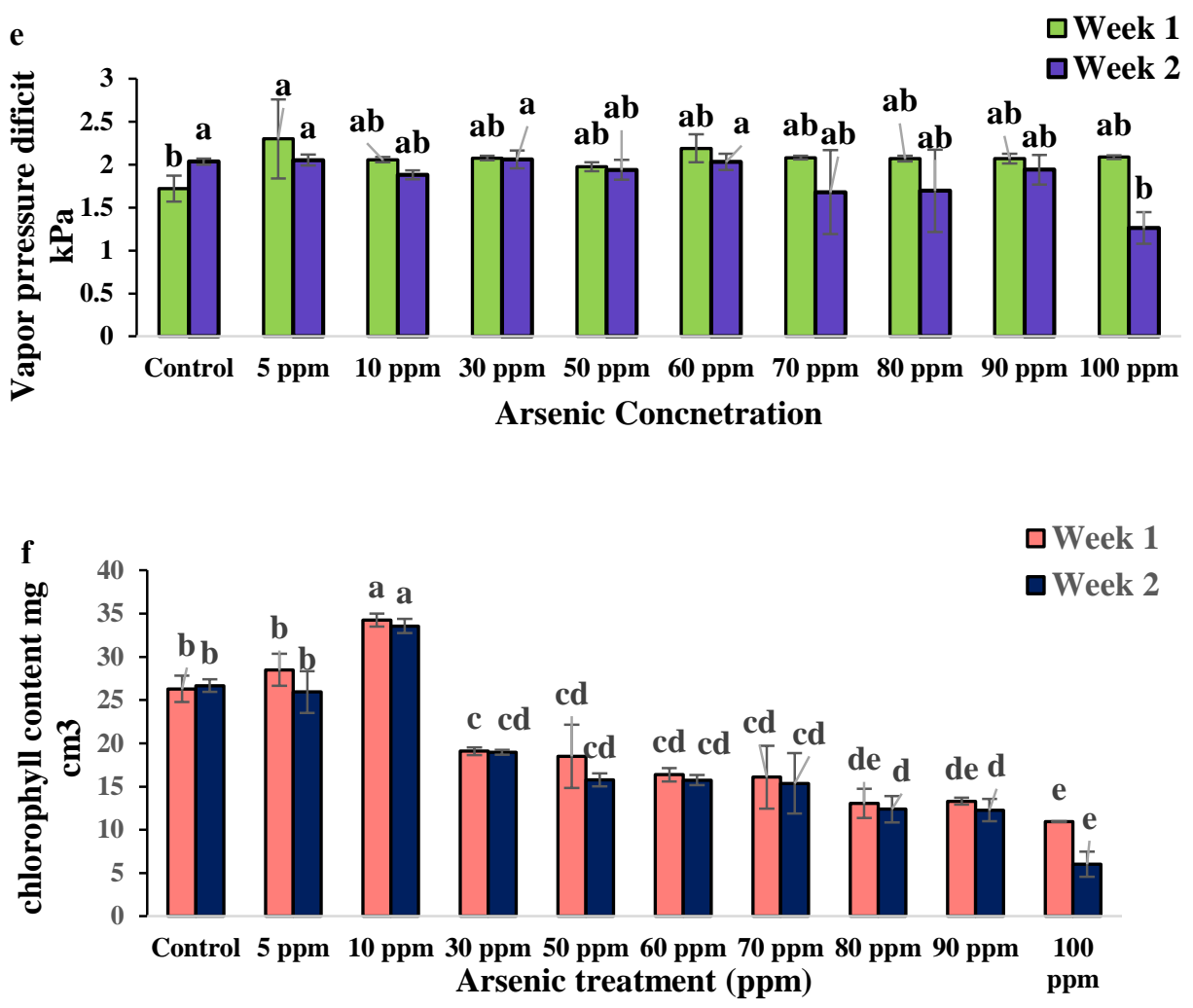

Figure 5. (a) Photosynthesis rate $\left(\mu \mathrm{mol} \mathrm{CO} \mathrm{m}^{-2} \cdot \mathrm{s}^{-1}\right)$; (b) Stomatal conductance $\left(\mathrm{mol} \mathrm{H}_{2} \mathrm{O} \mathrm{m}^{-2} \cdot \mathrm{s}^{-1}\right)$; (c) Intercellular $\mathrm{CO}_{2}$ concentration $\left(\mu \mathrm{mol} \mathrm{CO} \mathrm{Col}^{-1)}\right.$; (d) Transpiration rate $\left(\mathrm{mmol} \mathrm{H}_{2} \mathrm{O} \mathrm{m}^{-2} \cdot \mathrm{s}^{-1}\right)$; (e) air pressure deficit $(\mathrm{kPa})$; and (f) Chlorophyll content $\left(\mathrm{mg} / \mathrm{cm}^{3}\right)$, of water mimosas one and two weeks after arsenic treatment at different concentrations $(0,5,10,30,50,60,70,80,90$, and $100 \mathrm{ppm})$. One-way ANOVA was performed, and bars represent standard errors (SE) of the means of the treatments $(n=3)$ with the same species if not otherwise stated. Different letters indicate significant differences between arsenic concentrations according to Duncan's multiple range tests $(p \leq 0.01)$. Among the treatments, different letters indicate significant differences according to Duncan's multiple range test $(p \leq 0.05)$.

The highest air pressure deficit in water mimosas was obtained from plants treated with 5 ppm concentration of arsenic at $2.29 \mathrm{kPa}$ after seven days of treatment (Figure 5e). Contrariwise, the lowest air pressure deficit was recorded for the control plants followed by those treated with 50 ppm arsenic after seven days of treatment at 1.72 and $1.97 \mathrm{kPa}$, respectively. On the one hand, the highest air pressure deficit in water mimosas was obtained from plants under $30 \mathrm{ppm}$ arsenic concentration followed by those under 5 ppm arsenic concentration after seven days of treatment at 2.06 and $2.05 \mathrm{kPa}$, respectively. On the other hand, the lowest air pressure deficit was recorded for plants treated with 70 ppm arsenic followed by those under 80 ppm arsenic treatment after seven days of treatment at 1.68 and $1.69 \mathrm{kPa}$, respectively. The results indicated that water mimosas reacted most sensitively to metal pollution through significant reductions in gas exchange. Similar responses in terms of photosynthesis rate, stomatal conductance, and intercellular $\mathrm{CO}_{2}$ concentration, in this investigation, suggest that the different photosynthetic responses of both plant treatments to excess arsenic might be stronger due to the low pigment content and stomatal conductance stress caused by high arsenic toxicity. Arsenic exposure as an abiotic stress could also cause direct or indirect alternation and damage to plant cells over the construction of reactive oxygen species (ROS) [65]. During growth, the vapor pressure deficit has a slight impact on the transpiration efficiency of different genotypes at whole-plant and leaf levels [66]. The results of this study revealed that high concentrations of arsenic promote da higher negative impact on the vapor pressure deficit. These results were similar to a study on Bambusa vulgaris 
which indicated that $B$. vulgaris was affected by high heavy metal concentrations as exhibited by the lowest Vpdl recorded at the end of the arsenic treatment period [54]. A study on Zea mays' vapor pressure deficit recorded a $75 \%$ reduction as compared with respective stress controls [67].

The highest chlorophyll content for water mimosas was reported for plants under $10 \mathrm{ppm}$ arsenic concentration at $34.26 \mathrm{mg} / \mathrm{cm}^{3}$ after seven days (Figure $5 \mathrm{f}$ ). However, the lowest chlorophyll content was recorded for plants under $100 \mathrm{ppm}$ concentration of arsenic after seven days at $10.93 \mathrm{mg} / \mathrm{cm}^{3}$. In water mimosas, the highest chlorophyll content was observed in plants under $10 \mathrm{ppm}$ arsenic concentration at $33.56 \mathrm{mg} / \mathrm{cm}^{3}$ after 14 days. However, the lowest chlorophyll content for water mimosas was recorded for those treated with $100 \mathrm{ppm}$ arsenic at $6.03 \mathrm{mg} / \mathrm{cm}^{3}$ followed by water mimosas under $50 \mathrm{ppm}$ arsenic concentration after 14 days at $94.60 \mathrm{mg} / \mathrm{cm}^{3}$. Chlorophyll content as a biochemical parameter for water fern (Salvinia natans) was estimated along with exposure time to observe the variations in Salvinia biochemical constituents. The study showed that at the earliest contact hours, no significant negative impact on chlorophyll content was observed for plants under $2.0 \mathrm{ppm}$ first arsenic concentrations. However, a significant toxicity effect was obtained in the form of a $60 \%$ chlorophyll content loss after five days, even for initial arsenic concentrations. These results demonstrate the inactivation of the photosystem electron transport and a chloroplast membrane disorder due to arsenic treatments [68]. In B. vulgaris, the lowest chlorophyll content was observed at the highest heavy arsenic concentration (300 ppm) at the end of the treatment period [54].

Analysis of the water mimosas under different arsenic treatments on Day 14 showed various proline and MDA (lipid peroxidation) contents. The highest level of MDA was observed in $50 \mathrm{ppm}$ at $35.47 \pm 1.8$ and $37.23 \pm 0.80$ ( $\mu \mathrm{mol} / \mathrm{g} \mathrm{FW}$ ) for root and leaves, respectively (Table 4). Additionally, the level of MDA in the leaves was higher than in the roots under all arsenic treatments (Table 4). Subsequently, a higher level of proline was observed in the roots $(35 \pm 0.4 \mu \mathrm{mol} / \mathrm{g} \mathrm{FW})$ and leaves $(43 \pm 1.3 \mu \mathrm{mol} / \mathrm{g} \mathrm{FW})$ of the sample treated with $30 \mathrm{ppm}$ arsenic (Table 4). In the treated root samples, the lowest levels of proline were observed for plants treated with $90 \mathrm{ppm}(19 \pm 0.4 \mu \mathrm{mol} / \mathrm{g} \mathrm{FW})$ and $100 \mathrm{ppm}(19 \pm 0.5 \mu \mathrm{mol} / \mathrm{g} \mathrm{FW})$ arsenic (Table 4).

Table 4. Effect of different arsenic concentrations on proline and lipid peroxidation contents of water mimosa.

\begin{tabular}{ccccc}
\hline & \multicolumn{2}{c}{$\begin{array}{c}\text { MDA Contents } \\
(\mu \mathbf{m o l} / \mathbf{g} \text { FW })\end{array}$} & \multicolumn{2}{c}{$\begin{array}{c}\text { Proline } \\
(\mu \mathrm{mol} / \mathbf{g} \text { FW })\end{array}$} \\
\hline $\begin{array}{c}\text { Arsenic Concentrations } \\
(\mathbf{p p m})\end{array}$ & Root $^{\text {L }}$ & Leave & Root & Leave \\
\hline $\begin{array}{c}\text { Control } \\
\mathbf{5}\end{array}$ & $12.43 \pm 1.3^{\mathrm{g}}$ & $15.45 \pm 0.81^{\mathrm{h}}$ & $20 \pm 0.98^{\mathrm{fg}}$ & $22 \pm 0.54^{\mathrm{h}}$ \\
$\mathbf{1 0}$ & $25.54 \pm 1.02^{\mathrm{f}}$ & $26.84 \pm 1.36^{\mathrm{g}}$ & $23 \pm 0.87^{\mathrm{e}}$ & $35 \pm 1.39^{\mathrm{e}}$ \\
$\mathbf{3 0}$ & $26.76 \pm 0.9^{\mathrm{e}}$ & $28.43 \pm 1.21^{\mathrm{f}}$ & $28 \pm 0.23^{\mathrm{d}}$ & $37^{\mathrm{f}} \pm 1.3^{\mathrm{d}}$ \\
$\mathbf{5 0}$ & $32.87 \pm 1.2^{\mathrm{b}}$ & $31.34 \pm 0.98^{\mathrm{d}}$ & $35 \pm 0.4^{\mathrm{a}}$ & $43 \pm 1.3^{\mathrm{a}}$ \\
$\mathbf{6 0}$ & $35.47 \pm 1.8^{\mathrm{a}}$ & $37.23 \pm 0.80^{\mathrm{a}}$ & $33 \pm 1.93^{\mathrm{b}}$ & $41 \pm 1.74^{\mathrm{b}}$ \\
$\mathbf{7 0}$ & $31.21 \pm 1.01^{\mathrm{c}}$ & $34.09 \pm 0.90^{\mathrm{b}}$ & $30 \pm 0.94^{\mathrm{c}}$ & $39 \pm 0.87^{\mathrm{c}}$ \\
$\mathbf{8 0}$ & $28.65 \pm 0.87^{\mathrm{d}}$ & $33.35 \pm 1.89^{\mathrm{c}}$ & $27 \pm 0.76^{\mathrm{d}}$ & $28 \pm 0.36^{\mathrm{f}}$ \\
$\mathbf{9 0}$ & $26.67 \pm 0.67^{\mathrm{e}}$ & $30.12 \pm 1.24^{\mathrm{e}}$ & $21 \pm 0.89^{\mathrm{f}}$ & $25 \pm 0.87^{\mathrm{g}}$ \\
$\mathbf{1 0 0}$ & $20.76 \pm 0.56^{\mathrm{h}}$ & $24.34 \pm 1.78^{\mathrm{i}}$ & $19 \pm 0.4^{\mathrm{g}}$ & $22 \pm 0.87^{\mathrm{h}}$ \\
& $18.23 \pm 0.76^{\mathrm{i}}$ & $24.12 \pm 1.23^{\mathrm{i}}$ & $19 \pm 0.5^{\mathrm{g}}$ & $18 \pm 0.45^{\mathrm{i}}$ \\
\hline
\end{tabular}

Proline and lipid peroxidation contents were measured on the 14th day of experiment. MDA, lipid peroxidation. Different letters indicate significant differences between arsenic concentrations according to Duncan's multiple range tests $(p \leq 0.05)$.

The results strongly suggest that arsenic toxicity affects some of the vital enzymes needed for the antioxidant defence mechanism of water mimosas. It has been shown that MDA content was one of the most important mechanisms which could lead to plants' resistance against oxidative stresses, and therefore adaptation and increased survival rate under adverse conditions [69]. MDA is a reactive aldehyde which is produced by lipid peroxidation and is boosted under adverse conditions. 
Reportedly, MDA has been focused on as an oxidative stress indicator [70]. The MDA content could increase under heavy metal stress due to the concentration-dependent free radical production. The better the oxidative damage protection is, the more quickly the antioxidative system could be to upregulate. Peroxidizing activity can lead to the MDA elimination. An increase in antioxidative enzyme activity, such as peroxidizing activity, leads to MDA elimination, and subsequently, a reduction in $\mathrm{H}_{2} \mathrm{O}_{2}$ amount and the membrane damage [69]. These results showed that water mimosa was able to tolerate arsenic up to $30-50 \mathrm{ppm}$ (Table 4), in spite of the fact that lipid peroxidation was enhanced by this metalloid and, as a consequence, the cell membrane stability was affected [71,72]. The arsenic-dependent decrease in MDA accumulation in the range of 60-100 ppm could be attributed to the reduction in the survival rate of plants. Similarly, accumulation of proline is another index in a plant's defence mechanism against stresses. Proline is an osmo-compatible solute which raises the ability of water mimosas and other phytoremediation plants to endure toxicity from arsenic and other heavy metals [73]. In the current study, proline accumulation in the roots and leaves first increased to a peak value of $35 \pm 0.4(\mu \mathrm{mol} / \mathrm{g} \mathrm{FW})$ and $43 \pm 1.3(\mu \mathrm{mol} / \mathrm{g} \mathrm{FW})$, respectively, and then decreased. The results indicated that water mimosas could tolerate up to $30 \mathrm{ppm}$ of arsenic; after that, arsenic would damage the plant's mechanisms. Reportedly, the relationship between proline accumulation and arsenic level could be of a substrate-product nature, due to the direct or indirect impact of heavy metal stresses on proline biosynthesis [74]. This might be due to the relationship between proline and arsenic diverting from glutamate and practical indirect activities identifying with sub-products of arsenic catabolism such as gamma-aminobutyric acid (GABA) and $\mathrm{H}_{2} \mathrm{O}_{2}$ [75]. Interestingly, the stress-induced cellular acidification was reduced due to the proline's accumulation under stress. Proline might act as a singlet oxygen scavenger and hydroxyl radical, a carbon and nitrogen source required in stress recovery and a component of stress signal transduction mechanisms, thus contributing to the development of heavy metal tolerance [76].

\subsection{Phytoremediation Attributes of Water Mimosa under Arsenic Treatment}

\subsubsection{Arsenic Accumulation of Water Mimosa}

The ANOVA and Duncan's multiple comparison tests on the water mimosas were significant $(p \leq 0.01)$ in terms of ICP of the water mimosa plant removal efficiency after seven and 14 days. Non-significant differences were observed between the replicates (Table 5).

Table 5. ANOVA of arsenic accumulation $\left(\mathrm{mg} \cdot \mathrm{Kg}^{-1}\right)$ and removal efficiency (ppm) of water mimosa after arsenic treatment.

\begin{tabular}{ccccc}
\hline S.O.V & df & ICP Water Mimosa & $\begin{array}{c}\text { Removal Efficiency } \\
\text { after 7 Days }\end{array}$ & $\begin{array}{c}\text { Removal Efficiency } \\
\text { after 14 Days }\end{array}$ \\
\hline Concentrations & 9 & $277.330^{* *}$ & $47.31^{* *}$ & $81.06^{* *}$ \\
Replicate & 2 & $1.303^{\mathrm{ns}}$ & $0.709 \mathrm{~ns}$ & $0.750^{\mathrm{ns}}$ \\
Error & 18 & 0.7125 & 0.661 & 1.46 \\
Total & 29 & - & - & - \\
\hline C.V. & - & 5.290 & 8.419 & 9.54 \\
\hline \multicolumn{5}{r}{ S.O.V, source of variation. } \\
\end{tabular}

As shown in Figure 5, the water mimosas accumulated arsenic in their roots up to $2.8 \mathrm{mg} \cdot \mathrm{Kg}^{-1}$, even at the lowest concentration of arsenic ( $5 \mathrm{ppm}$ ) during the 14 days of experimentation. The water mimosas presented severe necrotic symptoms (Figures 2 and 3) at the highest concentrated condition (100 ppm) after 14 days of treatment. However, the plant was able to accumulate $16.36 \mathrm{mg} \cdot \mathrm{Kg}^{-1}$ arsenic in its roots ( $0.8 \mathrm{mg}$ total arsenic) (Figure 6). Plants exposed to $70 \mathrm{mg} \cdot \mathrm{L}^{-1}$ arsenic accumulated a concentration of $17 \mathrm{mg} \cdot \mathrm{Kg}^{-1}$ in their roots $(0.97 \mathrm{mg}$ total arsenic) and the highest accumulation was recorded at $30 \mathrm{ppm}$ with $28.192 \mathrm{mg} \cdot \mathrm{Kg}^{-1}$ (0.3 $\mathrm{mg}$ total arsenic). 


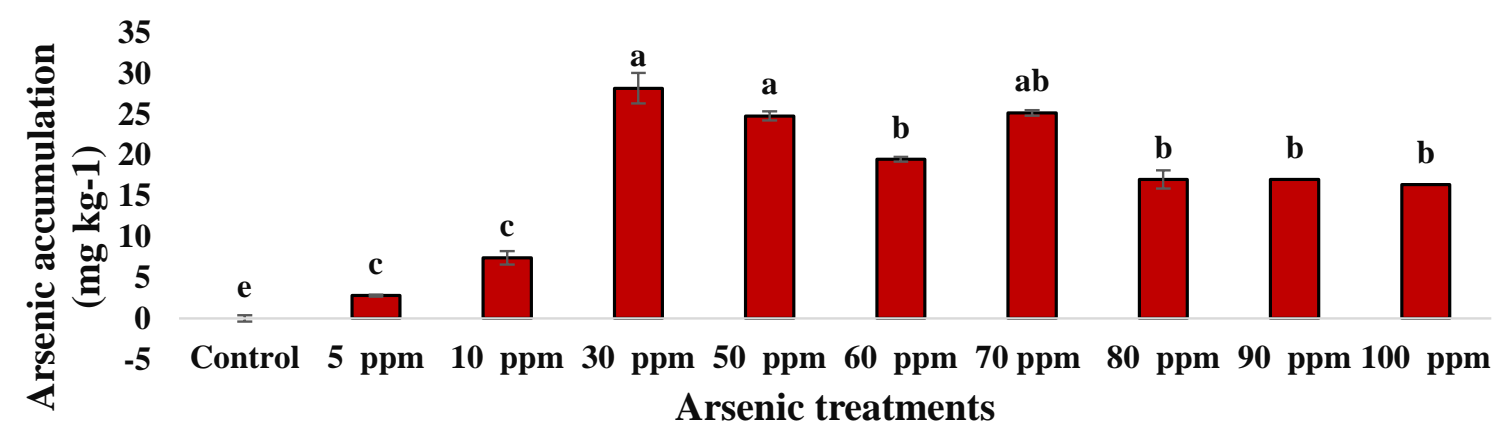

Figure 6. Arsenic accumulation $\left(\mathrm{mg} \cdot \mathrm{Kg}^{-1}\right)$ by water mimosas two weeks after arsenic treatments in different concentrations $(0,5,10,30,50,60,70,80,90$, and 100 ppm). One-way ANOVA was performed, and bars represent standard errors (SE) of the means of the treatments $(n=3)$ with the same species if not otherwise stated. Different letters indicate significant differences between arsenic concentrations according to Duncan's multiple range tests $(p \leq 0.01)$. Among the treatments, different letters indicate significant differences according to Duncan's multiple range tests $(p \leq 0.05)$.

Although arsenic has been recorded at the lowest arsenic treatment, small amounts of arsenic potentially have been translocated from the growth solution to the leaves [45]. A comparison of the amount of arsenic in plants and water showed that almost all arsenic accumulation was retained in the roots at $70 \mathrm{ppm}$ and only a small amount was translocated to the shoots. These findings are similar to previous studies on some hyper-accumulator plants with the capability of translocating arsenic from roots to above-ground [77]. However, this plant also showed general plant dysfunction at high concentrations. The same results were achieved in a study on purple willow (Salix purpurea) under 30 and $100 \mathrm{ppm}$ arsenic concentrations [45]. Interestingly, water hyacinths treated with 70 and $100 \mathrm{ppm}$ arsenic showed the same absorption of foliar-applied arsenic with the arsenic hyper-accumulating fern (Pteris vittata L.) [78]. Another examination on water hyacinth found a maximum uptake of arsenic at $0.0309 \mathrm{mg} / \mathrm{g}$ in its dry plant tissue [49]. In microorganisms, detoxification operons have been demonstrated as the most common arsenic resistance form against heavy metals [79]. In another study, two genes ( $a s o A$ and $a s o B$ ) were encoded as the subunit of oxidation of arsenite in Alcaligenes faecalis which was involved in metabolism processes and arsenic resistance [80]. It has been shown that, in Sulfurospirillum barnesi, the resistance mechanism of a single operon was encoded in the cell membrane where the reduction in arsenate occurs [81]. In previous reports, a majority of up-taken arsenic accumulated in the roots, thus providing reason for the authors to focus on the roots of each water mimosa plant $[45,77]$.

\subsubsection{Arsenic Effect on Removal Efficiency of Water Mimosa}

In water mimosas, the highest removal efficiency was observed for plants under $60 \mathrm{ppm}$ arsenic concentration at $13.73 \%$ after seven days of arsenic treatment (Figure 7). However, the lowest removal efficiency for water mimosas was recorded for those treated with $5 \mathrm{ppm}$ arsenic after seven days at $6.7 \%$ (Figure 7). The highest removal efficiency was reported for water mimosas under $60 \mathrm{ppm}$ arsenic concentration at $17.43 \%$ followed by those treated with $30 \mathrm{ppm}$ arsenic at $17.24 \%$ after 14 days of treatment (Figure 7). Nevertheless, the lowest removal efficiency for water mimosas was recorded for plants under 5 ppm arsenic concentration at $8.5 \%$ after 14 days of arsenic treatment (Figure 7).

In regard to the arsenic removal percentage at different concentrations, significant differences were recorded among the treatments. These findings are in line with previous studies, for example, Echinodorus cordifolius was found to have the highest arsenic removal efficiency, followed by some other aquatic plants, for instance Cyperus alternifolius, Acrostichum aureum and Colocasia esculenta., respectively [82]. The removal of arsenic was up to $38.8 \%$ for water hyacinth; the result paralleled another experiment carried out by Ingole and Bhole [49] who recorded a 32\% removal efficiency for water hyacinth when arsenic was present at an initial concentration $5 \mathrm{ppm}$. In the case of water 
mimosas' heavy metal uptake, according to previous research, the highest removal levels were for cadmium and lead as compared with other heavy metals [83]. This suggests that the removal rate of arsenic increases as the concentration increases, due to higher arsenic absorption by the roots into the plants, as has been proven by Darajeh et al. [84] using plant root length. Concentrations in plants and high removal efficiency may happen due to a plant's high biomass during growth, in addition to the metallophilic root system's proliferation associated with the possibility of arsenic cross-contamination from external sources that may lead to higher arsenic uptake [85].

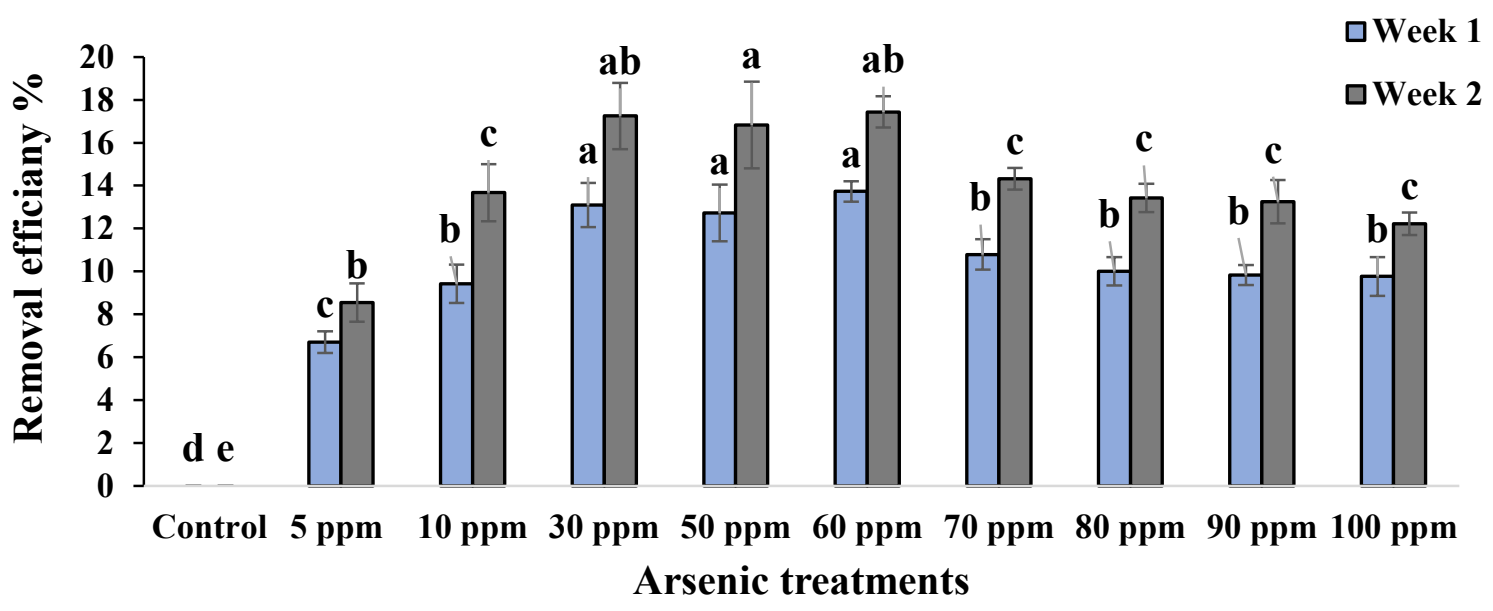

Figure 7. Removal efficiency (\%) of water mimosas two weeks after arsenic treatments in different concentrations $(0,5,10,30,50,60,70,80,90$, and $100 \mathrm{ppm})$. One-way ANOVA was performed, and bars represent standard errors (SE) of the means of the treatments $(n=3)$ with the same species if not otherwise stated. Different letters indicate significant differences between arsenic concentrations according to Duncan's multiple range tests $(p \leq 0.01)$. Among the treatments, different letters indicate significant differences according to Duncan's multiple range tests $(p \leq 0.05)$.

\subsubsection{Impact of Arsenic on Histology of Water Mimosa}

X-ray spectroscopy (EDX) (LEO 1455 VPSEM, London, UK) and scanning electron microscopy (SEM) observations were done on the roots of the control and $30 \mathrm{ppm}$ treated water mimosas after 14 days of treatment (Figure 8). The roots of the control plants were thinner than the roots of plants treated with arsenic (woody roots). The hairy roots of the control samples were thinner and young (Figure 8a), but the hairy roots of treated samples were woody and thick (Figure 8f). The epidermis of both control and treated samples was multi-layered. There were several parenchyma tissues with a rectangular structure in the control samples (Figure $8 b-d$ ). However, the parenchyma tissues had an irregular structure in the treated samples (Figure 8f-i). In the control samples, the cortex (outer layer of plant's root) generated circular intercellular nodules on its parenchyma cells. As compared with the control plants, the cortex of the treated samples were composed of irregular intercellular nodules on its parenchyma cells (Figure 8). The SEM analysis also proved the availability of arsenic in treated samples as compared with the controls (Figure 8j). The scanning electron microscopic analysis of Mimosa calodendron under arsenic treatment showed dissimilar changes in cell size. Arsenic can make visible changes to cell volume. This significant increase in the volume of the cell could be interpreted as a possible defence mechanism of the cell to avoid damage from arsenic toxicities through increasing arsenic acclamation [86]. 


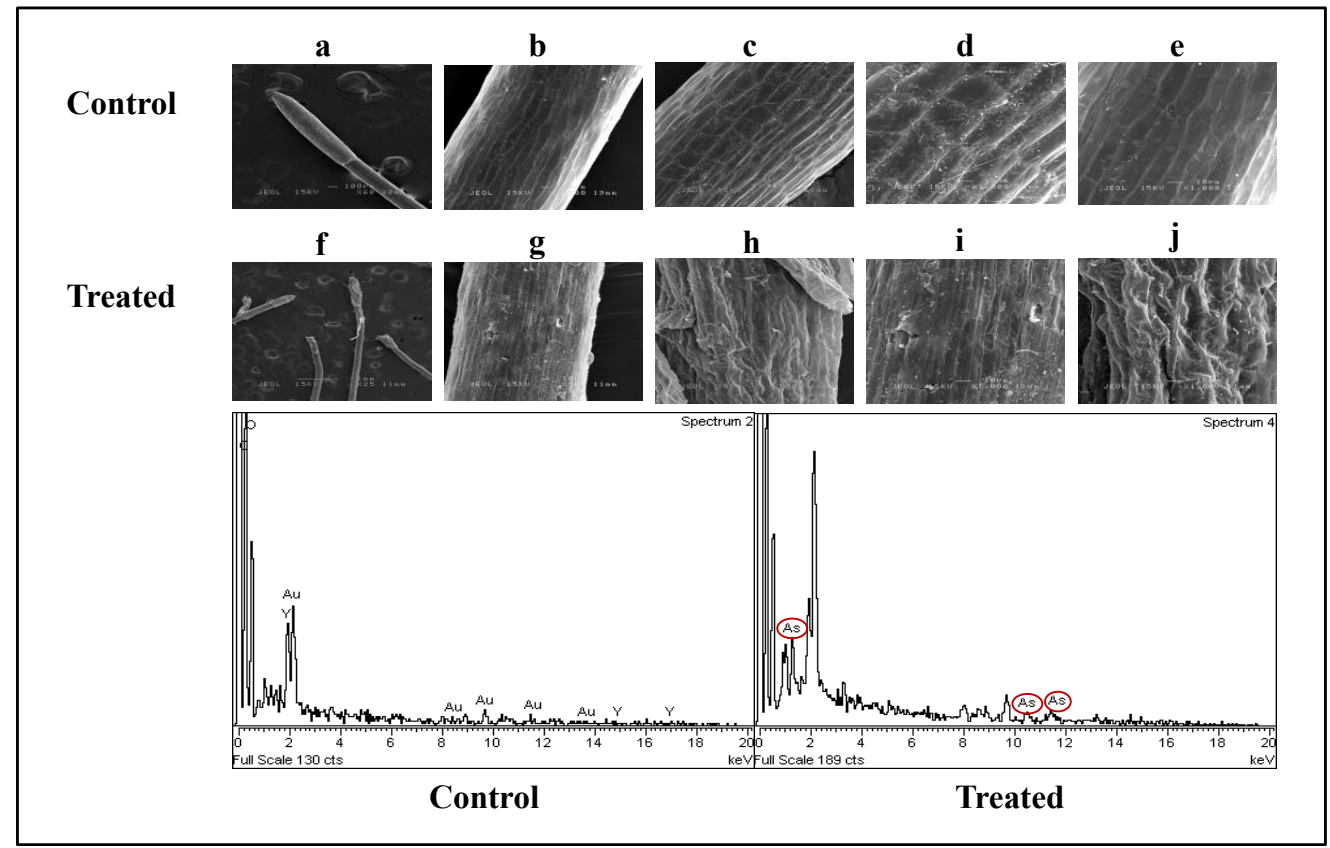

Figure 8. Scanning electron microscopic (SEM) observations were performed on the roots of three independent replications of control and treated (30 ppm sodium heptahydrate arsenate) water mimosa after 14 days of the exposure period. To measure the arsenic contents of root samples, three different spectrums of roots were randomly measured for each image. Comparison of control and treated samples is shown with thinner and younger hairy roots related to the control sample (a-e) woody, thick, and flaky hairy roots of treated samples $(\mathbf{f}-\mathbf{j}) .(\mathbf{e}, \mathbf{j})$ show the multi-layered epidermis with the smooth surface in control and rough and scaly in treated samples. Several parenchyma tissues have a rectangular structure in the control samples (c-e) while in treated one the structure shows irregularity $(\mathbf{f}-\mathbf{i})$. As compared with the control plants $(\mathbf{a}, \mathbf{b})$, the cortex of the treated samples are composed of irregular intercellular nodules on its parenchyma cells $(\mathbf{f}, \mathbf{g})$. Arsenic made visible changes to cell volume $(\mathbf{h}, \mathbf{j})$.

\section{Materials and Methods}

\subsection{Plant Materials and Culture Conditions}

Local naturally grown $N$. oleracea aquatic plants with similar weight and size were collected from Universiti Putra Malaysia's pond $\left(2^{\circ} 59^{\prime} 23.8^{\prime \prime} \mathrm{N}, 101^{\circ} 42^{\prime} 46.5^{\prime \prime} \mathrm{E}\right)$, and the plant species was confirmed by the Biodiversity Unit (UBD) at the Institute of Bioscience, Universiti Putra Malaysia. The collected plants were acclimatized under hydroponic conditions in tanks $(12 \times 25 \times 10 \mathrm{~cm}=3 \mathrm{~L})$ containing $0.20 \times$ of Hoagland solution with an aeration system.

\subsection{Arsenic Stress Treatment}

After one month of acclimatization, each plant was exposed to different levels of sodium heptahydrate arsenate $\left(\mathrm{Na}_{2} \mathrm{HAsO}_{4} \cdot 7 \mathrm{H}_{2} \mathrm{O}\right)$ concentrations as follows: 0 (control), 5 (67), 10 (135), 30 (400), 50 (667), 60 (801) 70 (933), 80 (1067), 90 (1200), and 100 (1335) ppm ( $\mu \mathrm{M})$, and the treated plants were kept, for two weeks, at $18-25^{\circ} \mathrm{C}$ with an $18 \mathrm{~h}$ light $/ 6 \mathrm{~h}$ dark photoperiod under a light intensity of $500 \mu \mathrm{mol} \cdot \mathrm{m}^{-2}$.

\subsection{Arsenic Stock Solution Preparation}

Different concentrations of sodium heptahydrate arsenate $\left(\mathrm{Na}_{2} \mathrm{HAsO}_{4} \cdot 7 \mathrm{H}_{2} \mathrm{O}\right)$ were measured based on the following equation: 
For the preparation of the 1000 ppm stock solution of arsenic, $4.16 \mathrm{~g}$ of $\mathrm{Na}_{2} \mathrm{HAsO}_{4} \cdot 7 \mathrm{H}_{2} \mathrm{O}$ was dissolved in $1000 \mathrm{~mL}$ of distilled water [45]. The application of treatment was randomized, and each tank's volume was maintained over 2 weeks to $3 \mathrm{~L}$ only by adding distilled water. The total amount of arsenic applied was 0, 15, 30, 90, 150, 180, 210, 240, 270, and $300 \mathrm{mg}$.

\subsection{Morphological Attribute Evaluation of N. oleracea under Arsenic Treatment}

Plant growth and physiological parameters were measured on the 1st and 14th day of plant treatment. First, the area/length, fresh weight and height, and growth ratio of the water mimosas' different parts were measured using a ruler, weight scale, and through visual observations. The root and shoot diameters were recorded using a digital Vernier calliper (Mitutoyo UK Ltd., Hampshire, UK).

\subsection{Relative Growth Rates}

The relative growth rates (RGR) of the water mimosas were measured as per the formula written in Equation (2) [87].

$$
\operatorname{RGR}=\left(\ln \mathrm{W}_{1}-\ln \mathrm{W}_{0}\right) /\left(\mathrm{t}_{1}-\mathrm{t}_{0}\right)
$$

where $W_{0}$ is the initial and $W_{1}$ is the final weights, while $t_{1}$ is the beginning and $t_{0}$ is the end of the treatment duration.

\subsection{Decreasing Ratio of Biomass (DRB) and Decreasing Ratio of Dry Weight (DRD)}

The decreasing ratio of biomass (DRB) and decreasing ratio of dry weight (DRD) were calculated based on the modified formula by Abiri et al. [88] as:

$$
\mathrm{DRD}=(\text { Drought weight of plants on day } 14 \times 100) /(\text { drought weight of plants on day } 1)-100
$$

\subsection{Relative Water Content}

The relative water content (RWC) was determined, according to Chen et al.'s [89] formula, as follows:

$$
\operatorname{RWC}(\%)=[(\mathrm{FW}-\mathrm{DW}) / \mathrm{FW}] \times 100
$$

where FW is the wet plant biomass which was measured immediately, and DW is the dry weight biomass of samples in an oven at $65^{\circ} \mathrm{C}$ after $48 \mathrm{~h}$ [40].

\subsection{Tolerance Index}

The tolerance index (Ti) was measured as follows:

$$
\mathrm{Ti}=(\text { dry weight treated plant }(\mathrm{g}) / \text { dry weight control plant }(\mathrm{g})) \times 100
$$

where water mimosas with $\mathrm{Ti} \geq 60 \%$ were reflected as highly tolerant [40].

\subsection{Physiological Features Assessment of N. oleracea under Arsenic Treatment}

\subsubsection{Chlorophyll Contents}

The chlorophyll contents of the leaves were collected in the morning at the same time weekly using a Konica Minolta SPAD 502Plus Chlorophyll Meter (Konica Minolta China Investment Ltd., Shanghai, China) which is a lightweight handheld meter that can be used without causing any damage to plants.

\subsubsection{Gas Exchange Attribute}

The fully expanded leaves of each plant were selected for this experiment. Gas exchange parameters including net photosynthesis rate (Anet), transpiration rate (E), stomatal conductance (Gs), 
intercellular CO2 (Ci), and leaf to air vapor pressure deficit (VpdL) were measured using a LiCor 6400 Portable Photosynthesis System (LiCor, Inc., Lincoln, NE, USA). This open-type photosynthesis system was equipped with a standard $3 \times 2 \mathrm{~cm}$ broadleaf cuvette. Calibration of the flow meter and $\mathrm{CO}_{2}$ zero values was made before the gas exchange was measured. Then, the $\mathrm{CO}_{2}$ concentration was set at $360 \mathrm{~mol} \cdot \mathrm{m}^{-2} \cdot \mathrm{s}^{-1}$ to avoid any effect from fluctuating environmental conditions. Cuvette irradiance, temperature, and relative humidity were set at $650 \mu \mathrm{mol} \mathrm{photons} \mathrm{m}^{-1} \cdot \mathrm{s}^{-1}$ (saturating irradiance), $25^{\circ} \mathrm{C}$, and $40 \%$, respectively.

\subsubsection{Proline Contents}

According to Bates et al. [90], the proline content of plants under control or arsenic stress was measured using the ninhydrin acid reagent. Briefly, the sample collection for proline content was done on Day 14 and in this regard, $500 \mathrm{mg}$ of leaf tissues were detached and homogenized in a cold mortar and pestle by adding $3 \% w / v$ sulfosalicylic acid $(5 \mathrm{~mL})$. Next, the homogenized phases were centrifuged at $10,000 \times \mathrm{g}$ for $15 \mathrm{~min}$. In the next step, $2 \mathrm{~mL}$ of the acid ninhydrin were added to the $2 \mathrm{~mL}$ of supernatant, and $2 \mathrm{~mL}$ glacial acetic acid. The preparation of acid-ninhydrin was done by warming agitation with $30 \mathrm{~mL}$ glacial acetic acid, $1.25 \mathrm{~g}$ ninhydrin, and $20 \mathrm{~mL} 6 \mathrm{M}$ phosphoric acid, until dissolved. Subsequently, the mixture was cooled at room temperature $\left(4^{\circ} \mathrm{C}\right)$ for $24 \mathrm{~h}$ by incubating the mixture at $100^{\circ} \mathrm{C}$ for $30 \mathrm{~min}$, the red brick color developed. Finally, $4 \mathrm{~mL}$ of toluene was transferred into the tubes which were vortexed for $30 \mathrm{~s}$. The top layer (chromophore containing toluene) was isolated and the absorbance was recorded at $520 \mathrm{~nm}$ in the spectrophotometer against blank toluene. The proline concentration was measured using the standard curve of L-proline $[90,91]$.

\subsubsection{Lipid Peroxidation Contents}

Lipid peroxidation (malondialdehyde (MDA)) was calculated, based on Davenport et al. [90]. About $200 \mathrm{mg}$ of root and leaves were collected and homogenized in $2 \mathrm{~mL}$ of $5 \%(w / v)$ trichloroacetic acid and, subsequently, centrifuged at 10,000 $\mathrm{rpm}$ for $10 \mathrm{~min}$ at $4{ }^{\circ} \mathrm{C}$. In the next step, $2 \mathrm{~mL}$ of $0.67 \%(w / v)$ thiobarbituric acid was added into $2 \mathrm{~mL}$ of supernatant and the incubating of the mixture was done in a boiling water bath for $30 \mathrm{~min}$ and, subsequently, centrifuged after cooling. The supernatant absorption was done at 450, 532, and $600 \mathrm{~nm}$. The MDA content was calculated as described below:

$$
\operatorname{MDA}\left(\mu \mathrm{mol} \cdot \mathrm{g}^{-1}\right)=[6.45 \times(\mathrm{A} 532-\mathrm{A} 600)-(0.56 \times \mathrm{A} 450)] \times \mathrm{Vt} / \mathrm{W}
$$

where $\mathrm{Vt}=0.0021$ and $\mathrm{W}=0.2$.

\subsection{Arsenic Content Analysis Using Inductively Coupled Plasma Optical Emission Spectrometry (ICP-OES)}

\subsubsection{Plant Sample Preparation and Acid Digestion Method}

The roots of control and treated plants were detached and weighed after 14 days of treatment. Whole samples were dried at $70{ }^{\circ} \mathrm{C}$ for two days in oven. The smaller pieces of dried tissues were sieved ( $2 \mathrm{~mm}$ size). All powdered samples were cooled down, and then accurately weighed at $0.5 \mathrm{~g}$, $5 \mathrm{~mL}$ of $10 \% \mathrm{HCl}$ was added to their container. To obtain a clean solution, the containers with the acid solution, was kept on a hot plate and digested. The dissolving of the final residue was done in $10 \mathrm{~mL}$ of $20 \% \mathrm{HNO}_{3}$ solution and boiled at $100{ }^{\circ} \mathrm{C}$ for one hour. Then, the solution was cooled and transferred quantitatively to a $50 \mathrm{~mL}$ volumetric flask by adding distilled water. Whatman's 42 filter paper was used for the samples' final filtration before the determination of the samples' metal concentrations with an ICP-OES Optima 7300 Perkin Elmer [92].

\subsubsection{Analysis of Arsenic Uptake from Water}

Water samples were taken from both control $\left(0 \mathrm{mg} \cdot \mathrm{L}^{-1}\right.$ of arsenic) and treated tanks at the 0 th, 7 th, and 14th days and kept at $4{ }^{\circ} \mathrm{C}$ to evaluate their arsenic content. The level of water inside each tank 
was kept constant by adding distilled water. Samplings were done at the same time and the arsenic contents of samples were analyzed using the ICP-OES.

The removal efficiency of arsenic was calculated, according to Darajeh et al. [84] equation as follows:

$$
\% \text { Removal efficiency }=\left(C_{\text {ini }}-C_{\text {fin }}\right) / C_{\text {ini }} \times 100
$$

where $C_{\text {ini }}$ is the initial concentration of synthetic mixture and $C_{\text {fin }}$ is the final concentration of the synthetic mixture.

\subsection{Detection of Arsenic in N. oleracea Samples Using Electron Microscopy Analysis}

\subsubsection{Sample Preparation for Electron Microscopy}

Roots $\left(1 \mathrm{~cm}^{2}\right.$ slices $)$ were cut, put into separate vials, and fixed in $4 \%$ glutaraldehyde (fixative) for 2 days at $4{ }^{\circ} \mathrm{C}$. Then, the samples were washed with $0.1 \mathrm{M}$ sodium cacodylate buffer $\left(\mathrm{NaO}_{2} \mathrm{As}\left(\mathrm{CH}_{3}\right) 2 \cdot 3 \mathrm{H}_{2} \mathrm{O}\right)$ for 3 changes of $30 \mathrm{~min}$. Post-fixation was done using $1 \%$ osmium tetroxide $\left(\mathrm{OsO}_{4}\right)$ for $2 \mathrm{~h}$, at $4{ }^{\circ} \mathrm{C}$. Rewashing was performed using $0.1 \mathrm{M}$ sodium cacodylate buffer for 3 changes of $30 \mathrm{~min}$. Dehydration was implemented using a series of acetone concentrations at different times.

\subsubsection{Localization of Sodium Hepta Hydrate Arsenate in Treated Samples}

Images and quantitative analysis of plant samples under sodium heptahydrate arsenate $\left(\mathrm{Na}_{2} \mathrm{HAsO}_{4} \cdot 7 \mathrm{H}_{2} \mathrm{O}\right)$ were obtained using energy-dispersive X-ray spectroscopy (EDX) (Leo 1455 VP-SEM, New England, USA) and scanning electron microscopy (SEM). To assess the amount of arsenic using EDX, energy to wavelengths were counted as follows:

$$
\text { Wavelength }(\mathrm{A})=12.3983 / \text { Energy }(\mathrm{keV})
$$

Three independent replicates of treated and control plants were utilized to show the consequence of accumulation of sodium heptahydrate arsenate in the roots of individual plant samples. To measure the arsenic contents of root samples, three different spectrums of roots were randomly measured for each image. The magnification and accelerating voltage of images were 3509 and $2000 \mathrm{kV}$, respectively [88].

\subsection{Statistical Analysis}

For morphological and physiological studies, a randomized complete block design (RCBD) was used for a total of 30 tanks distributed in 3 experimental blocks (10 arsenic concentrations $\times$ 3 replications). For the analysis of the data, the SAS software version 9.4 was applied. The level of significance was assessed from the analysis of variance (ANOVA). Duncan's multiple ranges were used to compare the mean values, and interpretations were made accordingly.

\section{Conclusions}

In summary, this investigation provided insight into the effect of arsenic stress on water mimosas and the plants' response. The results of the micromorphological analysis along with the qualitative observations proved water mimosas' tolerance up to $30 \mathrm{ppm}$ arsenic treatment. Increasing the arsenic treatment above $30 \mathrm{ppm}$ caused all of the plants' micromorphology to be damaged. The physiological traits analysis showed the toxicity effects of arsenic even at the initial stages of the experiment, which caused damage to the chlorophyll content, photosynthesis rate, stomatal conductance, intercellular $\mathrm{CO}_{2}$ concentrations, transpiration rate, and air pressure deficit. Observations on the proline content showed water mimosas' adequate tolerance under $30 \mathrm{ppm}$ of arsenic treatment. The inductively coupled plasma optical emission spectrometry (ICP-OES) showed the accumulation of arsenic in water mimosas in the range of 30-60 ppm. However, increases in the arsenic's toxicity caused the accumulation rate to decrease. The link between this step with the previous physiological micromorphological traits showed that at higher levels of arsenic toxicity, plants were highly likely to 
die, therefore, the decreasing trend of arsenic accumulation might be due to this decreasing survival rate. In parallel with the results of ICP on the water mimosas, a link was also observed between the arsenic accumulation and removal efficiency of arsenic in water. The X-ray spectroscopy (EDX) and scanning electron microscopy (SEM) results showed deformation of water mimosa tissues in response to severe levels of arsenic toxicity. All in all, the results of this investigation suggest that water mimosa can be a reliable phytobioremediator for polluted water with up to $30 \mathrm{ppm}$ concentrations of arsenic. However, further studies are needed on the plant's genomic and proteomic reactions and other biochemical responses against heavy metals like arsenic.

Author Contributions: Conceptualization, N.A., N.A.S. and S.A.A; methodology, N.A. and N.A.S.; validation, N.A., N.A.S. and S.A.A.; formal analysis, N.A. and R.A.; investigation, N.A. and N.A.S.; resources, N.A.S., S.A.A. and R.N.; data curation, N.A.S.; writing-original draft preparation, N.A.; writing-review and editing, N.A., N.A.S., S.A.A., R.N. and R.A.; visualization, N.A. and R.A.; supervision, N.A.S.; project administration, N.A.S.; funding acquisition, N.A.S. All authors have read and agreed to the published version of the manuscript.

Funding: This research was funded by GERAN PUTRA BERIMPAK, Universiti Putra Malaysia, grant number 9551400 .

Acknowledgments: This work was supported by GERAN PUTRA BERIMPAK, reference code 9551400 (Vot no.).

Conflicts of Interest: The authors declare no conflict of interest.

\section{References}

1. Weldeslassie, T.; Naz, H.; Singh, B.; Oves, M. Chemical contaminants for soil, air and aquatic ecosystem. In Modern Age Environmental Problems and Their Remediation; Springer: Cham, Switzerland, 2018; pp. 1-22. [CrossRef]

2. Subramaniam, K.; Ahmad, S.A.; Shaharuddin, N.A. Mini review on phenol biodegradation in Antarctica using native microorganisms. Asia Pac. J. Mol. Biol. Biotechnol. 2020, 28, 77-89. [CrossRef]

3. Utermann, J.; Aydın, C.T.; Bischoff, N.; Böttcher, J.; Eickenscheidt, N.; Gehrmann, J.; König, N.; Scheler, B.; Stange, F. Heavy metal stocks and concentrations in forest soils. In Status and Dynamics of Forests in Germany. Ecological Studies (Analysis and Synthesis); Wellbrock, N., Bolte, A., Eds.; Springer: Cham, Switzerland, 2019; Volume 237, pp. 199-229. [CrossRef]

4. Zakaria, N.N.; Roslee, A.F.A.; Gomez-Fuentes, C.; Zulkharnain, A.; Abdulrasheed, M.; Sabri, S.; Ramirez-Moreno, N.; Calisto-Ulloa, N.; Ahmad, S.A. Kinetic studies of marine psychrotolerant microorganisms capable of degrading diesel in the presence of heavy metals. Rev. Mex. Ing. Quim. 2020, 19, 1375-1388. [CrossRef]

5. Izatt, R.M.; Izatt, S.R.; Bruening, R.L.; Izatt, N.E.; Moyer, B.A. Challenges to achievement of metal sustainability in our high-tech society. Chem. Soc. Rev. 2014, 43, 2451-2475. [CrossRef] [PubMed]

6. Chen, C.; Li, L.; Huang, K.; Zhang, J.; Xie, W.-Y.; Lu, Y.; Dong, X.; Zhao, F.J. Sulfate-reducing bacteria and methanogens are involved in arsenic methylation and demethylation in paddy soils. ISME J. 2019, 13, 2523-2535. [CrossRef]

7. Abdul, K.S.M.; Jayasinghe, S.S.; Chandana, E.P.; Jayasumana, C.; De Silva, P.M.C. Arsenic and human health effects: A review. Environ. Toxicol. Pharmacol. 2015, 40, 828-846. [CrossRef]

8. Jasrotia, S.; Kansal, A.; Mehra, A. Performance of aquatic plant species for phytoremediation of arsenic-contaminated water. Appl. Water Sci. 2017, 7, 889-896. [CrossRef]

9. Novo, L.A.; Castro, P.M.; Alvarenga, P.; da Silva, E.F. Plant rhizobacteria-assisted phytoremediation growth-promoting of mine. In Bio-Geotechnologies for Mine Site Rehabilitation; Prasad, M.N.V., Favas, P.J.d.C., Maiti, S.K., Eds.; Elsevier: Amsterdam, The Netherlands, 2018; pp. 281-295. [CrossRef]

10. Abolayo, T.T. Comparative Analysis of Heavy Metals Presence in Soil and Water in Relation to Its Environs: A Case Study of Gbagede Dumpsite Area of Kwara State and Ilokun Dumpsite Area of Ekiti State. Ph.D. Thesis, Kwara State University, Malete, Nigeria, 2019.

11. Bolisetty, S.; Peydayesh, M.; Mezzenga, R. Sustainable technologies for water purification from heavy metals: Review and analysis. Chem. Soc. Rev. 2019, 48, 463-487. [CrossRef] 
12. Jayakumar, S.; Yusoff, M.M.; Rahim, M.H.A.; Maniam, G.P.; Govindan, N. The prospect of microalgal biodiesel using agro-industrial and industrial wastes in Malaysia. Renew. Sustain. Energy Rev. 2017, 72, 33-47. [CrossRef]

13. Sobahan, M.A.; Mir, S.I.; Zakaria, I.; Hossain, M. Surface water contamination due to industrial activities in Gebeng area, Kuantan, Malaysia. In Proceedings of the International Conference on Civil and Architecture Engineering (ICCAE'2013), Kuala Lumpur, Malaysia, 6-7 May 2013; pp. 6-7.

14. Ab Razak, N.H.; Praveena, S.M.; Aris, A.Z.; Hashim, Z. Drinking water studies: A review on heavy metal, application of biomarker and health risk assessment (a special focus in Malaysia). J. Epidemiol. Glob. Heal. 2015, 5, 297-310. [CrossRef]

15. Sakai, N.; Alsaad, Z.; Thuong, N.T.; Shiota, K.; Yoneda, M.; Mohd, M.A. Source profiling of arsenic and heavy metals in the Selangor River basin and their maternal and cord blood levels in Selangor State, Malaysia. Chemosphere 2017, 184, 857-865. [CrossRef]

16. Othman, F.; Uddin Chowdhury, M.; Wan Jaafar, W.Z.; Mohammad Faresh, E.M.; Shirazi, S.M. Assessing risk and sources of heavy metals in a tropical river basin: A case study of the Selangor River, Malaysia. Pol. J. Environ. Stud. 2018, 27, 1659-1671. [CrossRef]

17. Hwi, T.Y.; Ibrahim, Y.S.; Khalik, W. Microplastic abundance, distribution, and composition in Sungai Dungun, Terengganu, Malaysia. Sains Malays. 2020, 49, 1479-1490.

18. Fernandez-Luqueno, F.; López-Valdez, F.; Gamero-Melo, P.; Luna-Suárez, S.; Aguilera-González, E.N.; Martínez, A.I.; García-Guillermo, M.d.S.; Hernández-Martínez, G.; Herrera-Mendoza, R.; Álvarez-Garza, M.A.; et al. Heavy metal pollution in drinking water-a global risk for human health: A review. Afr. J. Environ. Sci. Technol. 2013, 7, 567-584. [CrossRef]

19. Aljaberi, F.Y. Studies of autocatalytic electrocoagulation reactor for lead removal from simulated wastewater. J. Environ. Chem. Eng. 2018, 6, 6069-6078. [CrossRef]

20. Fu, F.; Wang, Q. Removal of heavy metal ions from wastewaters: A review. J. Environ. Manag. 2011, 92, 407-418. [CrossRef] [PubMed]

21. Soussi, A.; Ferjani, R.; Marasco, R.; Guesmi, A.; Cherif, H.; Rolli, E.; Mapelli, F.; Ouzari, H.I.; Daffonchio, D.; Cherif, A. Plant-associated microbiomes in arid lands: Diversity, ecology and biotechnological potential. Plant Soil 2016, 405, 357-370. [CrossRef]

22. Wei, Z.; Hao, Z.; Li, X.; Guan, Z.; Cai, Y.; Liao, X. The effects of phytoremediation on soil bacterial communities in an abandoned mine site of rare earth elements. Sci. Total Environ. 2019, 670, 950-960. [CrossRef] [PubMed]

23. Prabakaran, K.; Lokanathan, M.; Kakade, B. Three dimensional flower like cobalt sulfide (CoS)/functionalized MWCNT composite catalyst for efficient oxygen evolution reactions. Appl. Surf. Sci. 2019, 466, 830-836. [CrossRef]

24. Arabnezhad, M.; Afarani, M.S.; Jafari, A. Co-precipitation synthesis of ZnO-TiO2 nanostructure composites for arsenic photodegradation from industrial wastewater. Int. J. Environ. Sci. Technol. 2019, 16, 463-468. [CrossRef]

25. Lee, S.-Y.; Ahmad, S.A.; Mustapha, S.R.; Ong-Abdullah, J. Ability of Ipomoea aquatica Forssk. to remediate phenol in water and effects of phenol on the plant's growth. Pertanika J. Sci. Technol. 2017, 25, 441-452.

26. Verasoundarapandian, G.; Darham, S.; Ahmad, S.A. Toxicity of molybdenum and microbial application in molybdenum reduction for bioremediation: A mini review. Malays. J. Biochem. Mol. Biol. 2019, 22, 46-51.

27. Nasr, M. Phytomanagement in Egypt: A sustainable approach for clean environment coupled with meeting future energy demand. In Waste Management in MENA Regions; Springer: Cham, Switzerland, 2020; pp. 93-109. [CrossRef]

28. Castaldi, P.; Silvetti, M.; Manzano, R.; Brundu, G.; Roggero, P.P.; Garau, G. Mutual effect of Phragmites australis, Arundo donax and immobilization agents on arsenic and trace metals phytostabilization in polluted soils. Geoderma 2018, 314, 63-72. [CrossRef]

29. Ossai, I.C.; Ahmed, A.; Hassan, A.; Hamid, F.S. Remediation of soil and water contaminated with petroleum hydrocarbon: A review. (2020). Environ. Technol. Innov. 2020, 17, 100526. [CrossRef]

30. Yadav, K.K.; Gupta, N.; Kumar, A.; Reece, L.M.; Singh, N.; Rezania, S.; Khan, S.A. Mechanistic understanding and holistic approach of phytoremediation: A review on application and future prospects. Ecol. Eng. 2018, 120, 274-298. [CrossRef]

31. Prabakaran, K.; Li, J.; Anandkumar, A.; Leng, Z.; Zou, C.B.; Du, D. Managing environmental contamination through phytoremediation by invasive plants: A review. Ecol. Eng. 2019, 138, 28-37. [CrossRef] 
32. Hoang, S.A.; Lamb, D.; Seshadri, B.; Sarkar, B.; Choppala, G.; Kirkham, M.B.; Bolan, N.S. Rhizoremediation as a green technology for the remediation of petroleum hydrocarbon-contaminated soils. J. Hazard. Mater. 2020, 401, 123282. [CrossRef] [PubMed]

33. Oniosun, S.; Harbottle, M.; Tripathy, S.; Cleall, P. Plant growth, root distribution and non-aqueous phase liquid phytoremediation at the pore-scale. J. Environ. Manag. 2019, 249, 109378. [CrossRef] [PubMed]

34. Shukla, A.; Srivastava, S. A review of phytoremediation prospects for arsenic contaminated water and soil. In Phytomanagement of Polluted Sites; Elsevier: Amsterdam, The Netherlands, 2019; pp. 243-254. [CrossRef]

35. Bhunia, D.; Mondal, A.K. Systematic analysis (morphology, anatomy and palynology) of an aquatic medicinal plant water mimosa (Neptunia oleracea Lour.) in Eastern India. Int. J. Life Sci. Biotechnol. Pharm. Res. 2012, 1, 290-319.

36. Visoottiviseth, P.; Francesconi, K.; Sridokchan, W. The potential of Thai indigenous plant species for the phytoremediation of arsenic contaminated land. Environ. Pollut. 2002, 118, 453-461. [CrossRef]

37. Wahab, A.; Ismail, S.S.; Abidin, E.Z.; Praveena, S. Neptunia oleracea (water mimosa) as phytoremediation plant and the risk to human health: A review. Adv. Environ. Biol. 2014, 8, 187-194.

38. Anokhina, T.O.; Kochetkov, V.V.; Zelenkova, N.F.; Balakshina, V.V.; Boronin, A.M. Biodegradation of phenanthrene by Pseudomonas bacteria bearing rhizospheric plasmids in model plant-microbial associations. Appl. Biochem. Microbiol. 2004, 40, 568-572. [CrossRef]

39. Mishra, V.K.; Tripathi, B.D. Concurrent removal and accumulation of heavy metals by the three aquatic macrophytes. Biores. Technol. 2007, 99, 7091-7097. [CrossRef] [PubMed]

40. Syuhaida, A.W.A.; Norkhadijah, S.I.S.; Praveena, S.M.; Suriyani, A. The comparison of phytoremediation abilities of water mimosa and water hyacinth. ARPN J. Sci. Technol. 2014, 4, 722-731.

41. Azimi, R.; Hossein Jafari, S.; Kianian, M.K.; Khaksarzade, V.; Amini, A. Studying arbuscular mycorrhiza symbiotic effects on establishment and morphological characteristics of Bromus kopetdaghensis in cadmium contaminated soil. Taiwan Water Conserv. 2016, 64, 82-91.

42. Muro-González, D.A.; Mussali-Galante, P.; Valencia-Cuevas, L.; Flores-Trujillo, K.; Tovar-Sánchez, E. Morphological, physiological, and genotoxic effects of heavy metal bioaccumulation in Prosopis laevigata reveal its potential for phytoremediation. Environ. Sci. Pollut. Res. 2020,1-18. [CrossRef]

43. Applewhite, P.B.; Gardner, F.T. Rapid leaf closure of Mimosa in response to light. Nature 1971, 233, 279-280. [CrossRef]

44. Hagihara, T.; Toyota, M. Mechanical signaling in the sensitive plant Mimosa pudica L. Plants 2020, 9, 587. [CrossRef]

45. Yanitch, A.; Brereton, N.J.; Gonzalez, E.; Labrecque, M.; Joly, S.; Pitre, F.E. Transcriptomic response of purple willow (Salix purpurea) to arsenic stress. Front. Plant Sci. 2017, 8, 1115. [CrossRef]

46. Dushenko, W.T.; Bright, D.A.; Reimer, K.J. Arsenic bioaccumulation and toxicity in aquatic macrophytes to gold-mine effluent: Relationship with environmental partitioning, metal uptake and nutrients. Aquat. Bot. 1995, 50, 141-158. [CrossRef]

47. Sahoo, P.K.; Kim, K. A review of the arsenic concentration in paddy rice from the perspective of geoscience. Geosci. J. 2013, 17, 107-122. [CrossRef]

48. Lyubenova, L.; Pongrac, P.; Vogel-Mikuš, K.; Mezek, G.K.; Vavpetič, P.; Grlj, N.; Regvar, M.; Pelicon, P.; Schröder, P. The fate of arsenic, cadmium and lead in Typha latifolia: A case study on the applicability of micro-PIXE in plant ionomics. J. Hazard. Mater. 2013, 15, 371-378. [CrossRef] [PubMed]

49. Ingole, N.W.; Bhole, A.G. Removal of heavy metals from aqueous solution by water hyacinth (Eichhornia crassipes). J. Water Supply Res. Technol. AQUA 2003, 52, 119-128. [CrossRef]

50. Abbas, G.; Murtaza, B.; Bibi, I.; Shahid, M.; Niazi, N.K.; Khan, M.I.; Amjad, M.; Hussain, M.; Natasha. Arsenic uptake, toxicity, detoxification, and speciation in plants: Physiological, biochemical, and molecular aspects. Int. J. Environ. Res. Public Health 2018, 15, 59. [CrossRef]

51. Reichman, S.M. The responses of plants to metal toxicity: A review forusing on copper, manganese \& zinc. Aust. Miner. Energy Environ. Found. 2002, 14, 22-26.

52. Bianconi, D.; Pietrini, F.; Massacci, A.; Iannelli, M.A. Uptake of cadmium by Lemna minor, a (hyper?-) accumulator plant involved in phytoremediation applications. E3S Web Conf. 2013, 1, 13002. [CrossRef]

53. Kartika, K.; Lakitan, B.; Wijaya, A.; Kadir, S.; Widur, L.I.; Siaga, E.; Meihana, M. Effects of particle size and application rate of rice-husk biochar on chemical properties of tropical wetland soil, rice growth and yield. Aust. J. Crop. Sci. 2018, 12, 817-826. [CrossRef] 
54. Wan Rafiekal, W.A.R.; Hazandy, A.H.; Arifin, A.; Mohd Kamil, I. Efficiency of Bambusa vulgaris to clean up heavy metal contaminants. Trans. Malays. Soc. Plant Physiol. 2016, 23, $200-205$.

55. Gautam, A.; Pandey, A.K.; Dubey, R.S. Effect of arsenic toxicity on photosynthesis, oxidative stress and alleviation of toxicity with herbal extracts in growing rice seedlings. Indian J. Agric. Biochem. 2019, 32, 143-148. [CrossRef]

56. Zu, Y.Q.; Sun, J.J.; He, Y.M.; Wu, J.; Feng, G.Q.; Li, Y. Effects of arsenic on growth, photosynthesis and some antioxidant parameters of Panax notoginseng growing in shaded conditions. Int. J. Adv. Agric. Res. 2016, 4, 78-88.

57. Vezza, M.E.; Llanes, A.; Traveglia, C.; Agostini, E.; Talano, M.A. Arsenic stress effects on root water absorption in soybean plants: Physiological and morphological aspects. Plant Physiol. Biochem. 2018, 123, 9-17. [CrossRef]

58. de Freitas-Silva, L.; de Araújo, T.O.; da Silva, L.C.; de Oliveira, J.A.; de Araujo, J.M. Arsenic accumulation in Brassicaceae seedlings and its effects on growth and plant anatomy. Ecotoxicol. Environ. Saf. 2016, 124, 1-9. [CrossRef] [PubMed]

59. Romdhane, S.; Spor, A.; Busset, H.; Falchetto, L.; Martin, J.; Bizouard, F.; Bru, D.; Breuil, M.-C.; Philippot, L.; Cordeau, S. Cover crop management practices rather than composition of cover crop mixtures affect bacterial communities in no-till agroecosystems. Front. Microbiol. 2019, 10, 1618. [CrossRef] [PubMed]

60. Singh, H.; Goomer, S. Arsenic-A hidden poison in water-soil-rice crop continuum. Int. J. Sci. Technol. Res. 2019, 8, 864-877.

61. Haider, I.; Andreo-Jimenez, B.; Bruno, M.; Bimbo, A.; Floková, K.; Abuauf, H.; Ntui, V.O.; Guo, X.; Charnikhova, T.; al-Babili, S.; et al. The interaction of strigolactones with abscisic acid during the drought response in rice. J. Exp. Bot. 2018, 69, 2403-2414. [CrossRef] [PubMed]

62. Srivastava, S.; Pathare, V.S.; Sounderajan, S.; Suprasanna, P. Nitrogen supply influences arsenic accumulation and stress responses of rice (Oryza sativa L.) seedlings. J. Hazard. Mater. 2019, 367, 599-606. [CrossRef] [PubMed]

63. Henry, C.; John, G.P.; Pan, R.; Bartlett, M.K.; Fletcher, L.R.; Scoffoni, C.; Sack, L. A stomatal safety-efficiency trade-off constrains responses to leaf dehydration. Nat. Commun. 2019, 10, 3398. [CrossRef]

64. Xu, X.W.; Wang, P.; Zhang, J.; Chen, C.; Wang, Z.; Kopittke, P.M.; Kretzschmar, R.; Zhao, F.-J. Microbial sulfate reduction decreases arsenic mobilization in flooded paddy soils with high potential for microbial Fe reduction. Environ. Pollut. 2019, 251, 952-960. [CrossRef]

65. Andrade-Linares, D.R.; Grosch, R.; Restrepo, S.; Krumbein, A.; Franken, P. Effects of dark septate endophytes on tomato plant perfor-mance. Mycorrhiza 2011, 21, 413-422. [CrossRef]

66. Rasheed, A.; Takumi, S.; Hassan, M.A.; Imtiaz, M.; Ali, M.; Morgunov, A.I.; Mahmood, T.; He, Z. Appraisal of wheat genomics for gene discovery and breeding applications: A special emphasis on advances in Asia. Theor. Appl. Genet. 2020, 133, 1503-1520. [CrossRef]

67. Mishra, V.K.; Upadhyaya, A.R.; Pandey, S.K.; Tripathi, B.D. Heavy metal pollution induced due to coal mining effluent on surrounding aquatic ecosystem and its management through naturally occurring aquatic macrophytes. Biores. Technol. 2008, 99, 930-936. [CrossRef]

68. Mukherjee, S.; Kumar, S. Adsorptive uptake of arsenic (V) from water by aquatic fern Salvinia natans. J. Water Supply Res. Technol. AQUA 2005, 54, 47-53. [CrossRef]

69. Zhang, F.Q.; Wang, Y.S.; Lou, Z.P.; Dong, J.D. Effect of heavy metal stress on antioxidative enzymes and lipid peroxidation in leaves and roots of two mangrove plant seedlings (Kandelia candel and Bruguiera gymnorrhiza). Chemosphere 2007, 67, 44-50. [CrossRef] [PubMed]

70. Hu, R.; Sun, K.; Su, X.; Pan, Y.X.; Zhang, Y.F.; Wang, X.P. Physiological responses and tolerance mechanisms to $\mathrm{Pb}$ in two xerophils: Salsola passerina Bunge and Chenopodium album L. J. Hazard. Mater. 2012, 205, 131-138. [CrossRef] [PubMed]

71. Ahmadi Mousavi, E.; Manochehri Kalantari, K.; Jafari, S.R. Change of some osmolytes accumulation in water-stressed colza (Brassica napus L.) as affected by 24-epibrassinolide. Iranian J. Sci. Technol. (Sci.) 2009, 33, 1-11.

72. Monem, R.; Mirsharifi, S.M.; Mirtaheri, S.M. Evaluation allelopathic effects of barley shoot aqueous extract on germination, seedling growth, cell membrance permeability and malondialdehyde content of corn weeds. Adv. Environ. Biol. 2012, 6, 2490-2495.

73. Zhao, J.; Shi, G.; Yuan, Q. Polyamines content and physiological and biochemical responses to ladder concentration of nickel stress in Hydrocharis dubia (Bl.) Backer leaves. Biometals 2008, 21, 665. [CrossRef] 
74. Ding, C.; Shi, G.; Xu, X.; Yang, H.; Xu, Y. Effect of exogenous spermidine on polyamine metabolism in water hyacinth leaves under mercury stress. Plant Growth Regul. 2010, 60, 61. [CrossRef]

75. Galston, A.W.; Kaur-Sawhney, R.; Altabella, T.; Tiburcio, A.F. Plant polyamines in reproductive activity and response to abiotic stress. Bot. Acta 1997, 110, 197-207. [CrossRef]

76. Saygideger, S.; Deniz, F. Effect of 24-epibrassinolide on biomass, growth and free proline concentration in Spirulina platensis (Cyanophyta) under $\mathrm{NaCl}$ stress. Plant Growth Regul. 2008, 56, 219-223. [CrossRef]

77. Sylvain, B.; Mikael, M.H.; Florie, M.; Emmanuel, J.; Marilyne, S.; Sylvain, B.; Domenico, M. Phytostabilization of $\mathrm{As}, \mathrm{Sb}$ and $\mathrm{Pb}$ by two willow species (S. viminalis and S. purpurea) on former mine technosols. Catena 2016, 136, 44-52. [CrossRef]

78. Bondada, B.R.; Tu, S.; Ma, L.Q. Absorption of foliar-applied arsenic by the arsenic hyperaccumulating fern (Pteris vittata L.). Sci. Total Environ. 2004, 332, 61-70. [CrossRef] [PubMed]

79. Lim, K.T.; Shukor, M.Y.; Wasohm, H. Physical, chemical, and biological methods for the removal of arsenic compounds. Biomed. Res. Int. 2014, 2014, 503784. [CrossRef] [PubMed]

80. Silver, S.; Phung, L.T. Genes and enzymes involved in bacterial oxidation and reduction of inorganic arsenic. Appl. Environ. Microbiol. 2005, 599-608. [CrossRef] [PubMed]

81. Afkar, E. Localization of the dissimilatory arsenate reductase in Sulfurospirillum barnesii strain SeS-3. Am. J. Agric. Biol. Sci. 2012, 7, 97-105.

82. Prum, C.; Dolphen, R.; Thiravetyan, P. Enhancing arsenic removal from arsenic-contaminated water by Echinodorus cordifolius-Endophytic arthrobacter creatinolyticus interactions. J. Environ. Manag. 2018, 213, 11-19. [CrossRef]

83. Ogamba, E.N.; Izah, S.C.; Ogbogu, M.J. Cadmium and lead level in Eichhornia crassipes from River Nun, Niger Delta, Nigeria. J. Adv. Biol. Basic Res. 2015, 1, 53-56.

84. Darajeh, N.; Idris, A.; Truong, P.; Abdul Aziz, A.; Abu Bakar, R.; Che Man, H. Phytoremediation potential of vetiver system technology for improving the quality of palm oil mill effluent. Adv. Mater. Sci. Eng. 2014, 2014, 683579. [CrossRef]

85. Sumiahadi, A.; Acar, R. A review of phytoremediation technology: Heavy metals uptake by plants. Iop Conf. Ser. Earth Environ. Sci. 2018, 142, 012023. [CrossRef]

86. Barbosa Felestrino, É.; de Almeida Barbosa Assis, R.; de Carvalho Lemes, C.G.; Ferreira Cordeiro, I.; Peixoto Fonseca, N.; Villa, M.M.; Marcio Moreira, L.; Vieira, I.T.; Kamino, L.H.Y.; do Carmo, F.F.; et al. Alcaligenes faecalis associated with Mimosa calodendron rizhosphere assist plant survival in arsenic rich soils. J. Soil Sci. Plant Nutr. 2017, 17, 1102-1115. [CrossRef]

87. Sarangi, B.K.; Tiwari, S.; Pandey, R.A. Efficacy of three different plant species for arsenic phytoextraction from hydroponic system. Environ. Eng. Res. 2014, 19, 145-149.

88. Abiri, R.; Shaharuddin, N.A.; Maziah, M.; Balia Yusof, Z.N.; Atabaki, N.; Sahebi, M.; Azizi, P. Quantitative assessment of indica rice germination to hydropriming, hormonal priming and polyethylene glycol priming. Chil. J. Agric. Res. 2016, 76, 392-400. [CrossRef]

89. Chen, J.; Shiyab, S.; Han, F.X.; Monts, D.L.; Waggoner, C.A.; Yang, Z.; Su, Y. Bioaccumulation and physiological effects of mercury in Pteris vittata and Nephrolepis exaltata. Ecotoxicology 2009, 18, 110-121. [CrossRef]

90. Bates, L.S.; Waldren, R.P.; Teare, I.D. Rapid determination of free proline for water-stress studies. Plant Soil 1973, 39, 205-207. [CrossRef]

91. Davenport, S.B.; Gallego, S.M.; Benavides, M.P.; Tomaro, M.L. Behaviour of antioxidant defense system in the adaptive response to salt stress in Helianthus annuus L. cells. Plant Growth Regul. 2003, 40, 81-88. [CrossRef]

92. El Maki, H.B.; Abdel Rahaman, S.M.; Idris, W.H.; Hassan, A.B.; Babiker, E.E.; El Tinay, A.H. Content of antinutritional factors and $\mathrm{HCl}$-extractability of minerals from white bean (Phaseolus vulgaris) cultivars: Influence of soaking and/or cooking. Food Chem. 2007, 100, 362-368. [CrossRef]

Publisher's Note: MDPI stays neutral with regard to jurisdictional claims in published maps and institutional affiliations. 